\title{
Biocatalysis in the Swiss Manufacturing Environment
}

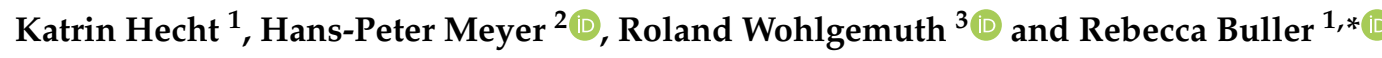 \\ 1 Competence Center for Biocatalysis, Institute of Chemistry and Biotechnology, Zurich University of \\ Applied Sciences, Einsiedlerstrasse 31, 8820 Wädenswil, Switzerland; Katrin.hecht@zhaw.ch \\ 2 HES-SO Valais-Wallis, Institute of Life Technologies, Route du Rawyl 64, 1950 Sion, Switzerland; \\ hpeter.meyer@hevs.ch \\ 3 Institute of Molecular and Industrial Biotechnology, Lodz University of Technology, \\ Stefanowskiego Street 4/10, 90-924 Lodz, Poland; roland.wohlgemuth.1@p.lodz.pl \\ * Correspondence: rebecca.buller@zhaw.ch; Tel.: +41-58-935-5438
}

Received: 16 November 2020; Accepted: 30 November 2020; Published: 4 December 2020

\begin{abstract}
Biocatalysis has undergone a remarkable transition in the last two decades, from being considered a niche technology to playing a much more relevant role in organic synthesis today. Advances in molecular biology and bioinformatics, and the decreasing costs for gene synthesis and sequencing contribute to the growing success of engineered biocatalysts in industrial applications. However, the incorporation of biocatalytic process steps in new or established manufacturing routes is not always straightforward. To realize the full synthetic potential of biocatalysis for the sustainable manufacture of chemical building blocks, it is therefore important to regularly analyze the success factors and existing hurdles for the implementation of enzymes in large scale small molecule synthesis. Building on our previous analysis of biocatalysis in the Swiss manufacturing environment, we present a follow-up study on how the industrial biocatalysis situation in Switzerland has evolved in the last four years. Considering the current industrial landscape, we record recent advances in biocatalysis in Switzerland as well as give suggestions where enzymatic transformations may be valuably employed to address some of the societal challenges we face today, particularly in the context of the current Coronavirus disease 2019 (COVID-19) pandemic.
\end{abstract}

Keywords: industrial biocatalysis; drug shortage; enzyme technology; Switzerland

\section{Biocatalysis in Switzerland}

Switzerland, situated in the heart of Europe, is considered a preferred test ground for products about to be introduced onto the European market [1]. Apart from the fact that three main European languages are spoken and a rich and diverse cultural background shapes its society, factors such as the well-educated and affluent population are also key as to why US companies such as Starbucks and McDonalds used Switzerland as a test bed for planned overseas expansion.

In the context of our biocatalysis analysis, similar considerations apply. Thanks to the highly developed chemical and pharmaceutical industry covering many important sectors to which biocatalysis may valuably contribute, Switzerland represents an excellent model for a study on the adoption of biocatalysis in industrial manufacturing. Thus, to tie in with our previous overview on the status of industrial biocatalysis [2], we revisited the Swiss chemical landscape by carrying out interviews with representatives of academia and of a subset of the more than 1000 small and large Swiss chemical and pharmaceutical companies. In addition, we analyzed the global and local patent situation and summarized recent biocatalysis trends from Swiss industry and academia hinting at future developments. Finally, by considering the drug shortages reported during the COVID-19 pandemic, which uncovered the inadequacy of current supply chains, we set out to delineate for selected examples 
how biocatalysis may contribute toward the relocation of selected manufacturing steps to Europe and Switzerland.

\subsection{The Chemical and Pharmaceutical Industry}

The pharmaceutical chemical industry is the most important export sector, contributing close to $47 \%$ of the total exports from Switzerland in 2019 [3]. The nominal value added by the pharmaceutical industry was CHF 351 per working hour in 2016 [4]. Thanks to the employment effect of the pharmaceutical industry, a further 207,300 persons were additionally employed in other branches. Overall, the pharmaceutical industry generated an aggregated employee income of $\mathrm{CHF} \sim 22$ billion in 2018.

Today, the Swiss chemical industry as a whole is focused on the life science market and on chemical specialties [5]. Notably, in the pharmaceutical chemical industry, biotechnology is a key asset and, consequently, strongly contributes to the contemporary Swiss economy. The history of the Swiss biotechnology industry has been marked by a continuous reinvention and a consequent focus on innovative higher value products, leading to Switzerland becoming (relative to the size of the country) the number one in therapeutic biopharmaceuticals and cell therapies. Biocatalysis, or the one- or up to multi-step conversion of substrates to products catalyzed by enzymes or whole cells (alive or dead) is in many aspects methodologically closely related to chemical synthesis. Consequently, the technology is strongly rooted in the manufacturing of small molecule drugs (APIs) and their intermediates.

To analyze the status of biocatalysis implementation in chemical manufacture, the authors have carried out interviews and have studied a subset of the 900 to 1000 chemical and pharmaceutical companies in Switzerland (Listing 1) [2]. The evaluation of previous and current interviews with a selection of academic and industrial stakeholders can be summarized as follows:

- An increasing number of companies are considering using enzymes in their chemical synthesis approaches every year.

- Enzyme steps are typically considered opportunistically if the enzyme is available in commercial quantities.

- For companies without in-house fermentation facilities and prior biocatalysis experience, it is perceived that only hydrolytic enzymes are readily available in industrial quantities for manufacturing purposes.

- Industrial interviewees signaled the need for a broader enzyme toolbox containing ready-to-use enzymes.

- Unlike our European neighbors, there are no Swiss CDMOs (Contract Development and Manufacturing Organizations) and service companies offering support in enzyme R\&D, piloting and production.

- Academia tends to have a more positive view of the industrial applicability of biocatalysis than industry.

- Besides the pharmaceutical industry, the fragrance and flavor industry should play a leading role and drive innovation in biocatalysis. 
Listing 1. The companies listed below operate in Switzerland in synthetic route scouting, process research and development and/or large-scale synthesis, the production of organic chemicals, intermediates, and small molecule active pharmaceutical ingredients (APIs). The list also features a selection of Swiss organizations involved in the topic of biocatalysis (bottom).

\section{Companies}

Aschem GmbH. Swiss fine chemical SME (Small Medium Enterprise) founded in 2018 by a Chinese entrepreneur focusing on the design, synthesis, and production of building blocks for drug discovery and services involving nanomaterials. Example of a Swiss company having strong connections to China relying on Chinese partners for $R \& D$ and production. The strong ties are manifested in the use of Chinese characters in the company logo.

AVA Biochem. AVA Biochem is a private company located in Muttenz, subsidiary of AVA-CO2 (former Avalon Industries AG) in Zug. The company produces the furan-based platform chemical 5-hydroxymethylfurfural (5-HMF) from renewable carbohydrates in ton quantities. AVA-Biochem uses a thermo-chemical process for the conversion of waste biomass, which is not competing with the food supply chain. 5-HMF is the starting material for the production of furan dicarboxylic methyl ester or polyethylene furanoate. The company currently supplies ton quantities out of its Muttenz pilot plant but is presently investing in manufacturing facilities in Europe.

AZAD. Azad Pharma AG is a private company from Schaffhausen established in 2000 to handle Cilag's API portfolio. The small company focuses on small molecules that are difficult to synthesize. Together with local applied universities, AZAD developed new synthetic routes to established and recently approved drugs, without infringing existing patents. Process development is managed from Schaffhausen with CDMOs in Europe, Taiwan, India, or China.

Axpo. The production and distribution of energy is the main business of this public company. In addition, Axpo is also Switzerland's most important producer of renewable energy. Axpo Biomass operates 15 fermentation plants (SST solid state fermentation) recycling biowaste from more than 2500 customers. The company advertises that up to $1000 \mathrm{kWh}$ energy and $900 \mathrm{~kg}$ of natural fertilizer can be produced with 1 ton of biowaste. Axpo Compogas AG offers disposal and recycling services for organic wastes.

Bachem. Founded in 1971, this public company specializes in the development and production of peptides, with sales of 314 million in 2019 and a total of 1200 employees. The company carried out 150 cGMP projects targeting new chemical entities (NCEs). As of 2019, the synthesis and production of oligonucleotides is a new service added to the portfolio of the company. Bachem plans to increase sales to CHF 500 million within the next three years, CHF 100 million of which should be contributed by the new oligonucleotide business.

BASF Schweiz AG. Ciba Specialty Chemicals was acquired and integrated into the BASF organization in 2009 and renamed BASF Schweiz AG in March 2010. Ciba was one of the founding members of the Swiss Industrial Biocatalysis Consortium (SIBC). BASF Schweiz has nine sites counting 1600 employees. The site Schweizerhalle focuses on the development of new products and improves existing processes. At the time, Ciba applied biocatalytic steps for the production of specialty monomers by transesterification and employed lipase-catalyzed resolutions.

Biosynth Carbosynth. Biosynth Carbosynth was founded in 1965 and today employs approximately 500 employees. Headquartered in Switzerland, this private company operates in Switzerland, UK, Slovakia, and China, offering a wide range of products such as biochemicals, chemical intermediates, APIs, and natural products for the life sciences. They are a niche API manufacturer and operate reactors between $50 \mathrm{~L}$ and $2500 \mathrm{~L}$ in Switzerland, including CMO services. Enzymatic reactions are possible.

Cerbios-Pharma SA. 100\% family-owned company founded in 1980, headquartered in Barbegno-Lugano with 132 employees generating sales of CHF 26 million. Cerbios offers third party CDMO services for APIs, HPAPIs, Biologics, and ADCs. For the latter, Cerbios, AGC Biologics, and Oncotec formed a collaboration called Proveo in 2015 to provide services for antibody drug conjugates. Cerbios' facilities are located in Barbengo-Lugano (TI) and in Couvet (NE) under the name of GMT SA Fine Chemicals. Growth of Cerbios was mainly driven by the chemical divisions' activity. Biocatalytic steps are evaluated in API process development, such as in the case of a process for the formylation of tetrahydrofolic acid with a transferase.

Cilag. Cilag (Chemical Industrial Laboratory) started activities in 1936 and became a part of the Johnson \& Johnson family. Today, it is a unit of Janssen, the pharmaceutical division of Johnson \& Johnson. Cilag is one of the larger Swiss manufacturer of small molecule APIs and drug substances with about 1200 employees. The company focuses on difficult to synthesize molecules, both from a process as well as intellectual property point of view. The company has shifted away from large scale manufacturing in Switzerland, instead concentrating on products with a higher value added, such as compounds requiring high containment installations. 
Listing 1. Cont.

Corden Pharma. Corden Pharma is a full-service CDMO with 1570 employees, which was founded in 1980. Since 2006, Cordon Pharma has been part of the cGMP pharma service and manufacturing platform of the International Chemical Investors Group (ICIG) with sites in Europe and the US. The facility in Liestal (reaction vessels up to $2.5 \mathrm{~m}^{3}$ ) offers process development and cGMP manufacturing for small molecule APIs, intermediates, and chiral building blocks, with special expertise in synthetic lipids, carbohydrates, and conjugates thereof. Biocatalysis is not a strategic direction at Corden Pharma, although a few enzymatic processes have been carried out in the Liestal facility. The parent company ICIG recently acquired a former Sandoz site in Germany with a total fermenter volume of $3000 \mathrm{~m}^{3}$ currently producing non cGMP food and feed enzymes.

Clariant. Clariant is a public company founded 1995 as a spin-off from the chemical business of Sandoz during the formation of Novartis. Clariant has 18,000 employees generating group sales of CHF 6.62 billion. Clariant's life science related products include personal care chemicals, crops, and the biocides business. In 2011 Clariant acquired Süd-Chemie AG and their Sunliquid ${ }^{\circledR}$ process and plant in Straubing (Bavaria) for the production of cellulosic ethanol from agricultural waste streams, i.e., from non-food sources. The associated know-how can also be used for other bio-based chemicals such as propylene, isobutylene, or ethylene oxide. Liquebeet ${ }^{\circledR}$ is a sugar beet-based carbon and energy source for fermentations.

DOTTIKON EXCLUSIV SYNTHESIS AG. Founded in 1913, the company manufactures exclusive APIs, high-quality intermediates, and performance chemicals. DOTTIKON is employing a one-site strategy and is currently in the midst of a major capacity expansion. DOTTIKON ES HOLDING AG, the parent company, is listed in the main segment of the SIX Swiss Exchange. With over 600 employees in Dottikon/Switzerland and sales of CHF 175 million (2019/20), DOTTIKON is a strategic development and manufacturing partner providing full CDMO services with know-how in hazardous reactions, high-pressure processes, low-temperature and flow chemistry. A wide spectrum of reaction conditions and OEBs (occupational exposure bands) down to $1 \mu \mathrm{g} / \mathrm{m}^{3}$ in reactors from 100 to $12,500 \mathrm{~L}$ allow them to synthesize different types of small molecules.

DSM. Royal DSM Global Dutch company is active in nutrition, health, and sustainable living. The company counts 23,000 employees and generates approximately EUR 10 billion in sales. Through the acquisition of the former Roche vitamin and fine chemicals business, DSM Nutritional Product has three manufacturing sites in Switzerland. DSM Nutritional Products headquarters and R\&D center are located in Kaiseraugst, Sisseln, with 1000 employees, producing vitamin E, vitamin A, vitamin K, astaxanthin, folic acids, and other products. DSM Lalden, with 160 employees, produces precursors used in vitamin production. With the acquisition of the Swiss SME Pentpharm in 2007 DSM acquired expertise in API proteins from snake and other natural sources. Biotechnology (biosynthesis and biocatalysis) is a key technology for DSM, a SIBC founding member. With the divestment of stake in Patheon, custom manufacturing is not an activity of DSM anymore.

Evolva. Evolva is a Swiss biotech company focused on the research, development, and commercialization of nature-based ingredients using engineered bacteria and yeast. The public SME counts approximately 70 employees. The company received US EPA registration for nootkatone (NootkaShield ${ }^{\mathrm{TM}}$ ), a next-generation protection against insect-borne diseases, in August 2020. Other products include several formulations of resveratrol, a compound associated with health benefits. After launching the cold-water dispersible resveratrol powder, Veri-Sperse $^{\mathrm{TM}}$, in 2019, Evolva followed up with another formulation, named Veri-te Aqua ${ }^{\mathrm{TM}}$, a soluble resveratrol that was developed based on a market need, especially in functional beverages. Evolva plans to launch another product, EVE-X157/Z4, under its flavor and fragrance sector by the end of 2020. The first commercial-scale production of EVERSWEET ${ }^{\mathrm{TM}}$, a non-artificial zero-calories stevia sweetener, was launched in November 2019 at Cargill's fermentation facility in Blair, Nebraska (USA).

Firmenich. Founded in 1895, Firmenich is the world's largest privately-owned fragrance and flavor company, recording a revenue of CHF 3.9 billion for the fiscal year 2019. Firmenich has 7600 employees and invests $10 \%$ of its turnover in R\&D. The company is leading in its industry regarding biotechnological manufacturing principles. CLEARWOOD ${ }^{\circledR}$, AMBROX $^{\circledR}, \mathrm{Z} 11$, or Dreamwood ${ }^{\mathrm{TM}}$ are examples of perfumery ingredients using biotechnological manufacturing principles.

Givaudan. Founded in 1895, this global flavor and fragrance company employs 12,000 people and generated CHF 6.6 billion in 2019. Givaudan uses organic chemical synthesis and biotechnological means for ingredient production. It has established a strong biotech R\&D to implement biotechnological manufacturing principles, among them the patented application of laccases or the use of squalene hopene cyclase for the production of (-)-Ambrox. Givaudan also operates a marine biotechnology center of excellence in Brittany for the development of novel algae-based cosmetic products. In addition, the F\&F company has strengthened its biotechnology sector with a number of acquisitions, including the French company Soliance, which specializes in microbial and microalgae product sourcing. Givaudan is a founding member of the SIBC. 
Listing 1. Cont.

Huntsman. Huntsman is a US multinational manufacturer of chemical products for consumers and industry.
In 2006, Huntsman purchased the CIBA textile effect business of Ciba Specialty Chemicals in Basel with 4200
employees. The Huntsman division "Advanced Materials" operates a manufacturing site in Monthey (Valais).
Plans to merge Clariant and Huntsman failed in 2017 due to an activist investor who acquired a quarter of
Clariant shares to stop the deal.
Inofea. Established in 2011 and incorporated in early 2014 in Basel, this SME has developed a new enzyme
platform (enzzen ${ }^{\circledR}$-enzymes) to supply more stable enzymes to industry, which would also be suitable for
continuous processing. The enzyme stabilization is achieved via a proprietary immobilization technique and
tailor-made shield, an enabling technology offered to customers.
Lonza. Lonza is a public company founded in 1897, which counts approximately 15,400 employees today. Lonza
is Switzerland's largest CMO. The company operates globally and generated sales of CHF 5.9 billion in 2019.
Lonza was one of first companies applying biotechnology in chemical synthesis in the early 1980 s to obtain
optically active intermediates and enantiomerically pure drugs and continues to use biocatalysis opportunistically
in chemicals synthesis. Today, Lonza is the largest CMO manufacturer of monoclonal antibodies. The chemical
division "Specialty Ingredients" is to be sold, while the biopharmaceuticals business is massively expanding
through the Ibex ${ }^{T M}$ project located in Visp. Lonza is a founding member of the SIBC.

Nestlé. Nestlé was formed in 1905 by the merger of the Anglo-Swiss Milk Company with Farine Lactée of Henri Nestlé. Nestlé employed 291,000 people and generated sales of CHF 92.6 billion in 2019. The Nestlé R\&D has expertise in biotransformation which are harnessed in several of its R\&D and Product Technology Centres. Biotechnology is an important manufacturing tool for Nestlé as showcased by the production of MAGGI Liquid Seasoning, which is based on wheat gluten fermentation. Enzyme technology is applied in extraction processes for a chocolate malt beverage or for cereal products. Nestlé also uses probiotics in many products. Nestlé acquired Aimmune Therapeutics to gain a leading position in food allergy prevention and treatment.

Nitrochemie. Swiss-German conglomerate between the Ruag MRO Holding and Rheinmetall AG. Among other activities, the company carries out custom manufacturing and process development for chemical intermediates.

Novartis. Figures among the top three pharmaceutical companies in the world together with Swiss competitor Roche. Novartis uses biotechnological and biocatalytic methods for small and large molecule production and drug metabolite production. Novartis was an early adopter of biocatalysis in drug manufacturing and is a founding member of the SIBC.

Merck. Merck is a science and technology company with the business sectors healthcare, life science, and performance materials generating sales of EUR 16 billion with 57,000 employees. The origin of the company goes back to 1668 when Friedrich J. Merck founded a pharmacy in Darmstadt. Merck is active since 1929 in Switzerland with nine sites, including five manufacturing sites with a total of 2370 employees. In 2006, Merck acquired Serono for the production of biotech-based medicines, followed by the acquisition of the life science company Sigma-Aldrich in 2015. The Buchs site with 450 employees was originally the site of the Swiss fine chemical company Fluka, founded in 1950 by the Swiss pharmaceutical companies Ciba, Geigy, and Hoffmann-La Roche. Biocatalysis has always been an important technology for analytical and manufacturing applications at the Buchs site. Sigma-Aldrich is a SIBC founding member.

Perseo. Based on its enzzen ${ }^{\circledR}$-technology, Inofea AG founded Perseo Pharma AG in 2019, a pharma product development company with a focus on therapeutic enzymes for the treatment of cancer, gastrointestinal, and rare genetic diseases.

Proveo. Collaboration between Cerbios, AGC Biologics and Oncotec since 2015 to provide services for antibody drug conjugates.

Roche. Roche belongs to the top five global pharmaceutical companies. The company uses, among others, biotechnological and biocatalytic methods for small and large molecule production. Biocatalysis work is dedicated to process R\&D and used for the generation of drug metabolites. Especially the production of chiral intermediates via enzymatic steps renders biocatalysis an attractive alternative to classical organic chemistry. Another focus is the replacement of metal catalysts to avoid toxicology problems due to heavy metal contaminations. Enzyme production (fermentation) and strain development is outsourced to contract research organizations (CROs) but can be produced in house on lab scale. A broad range of enzymes are used. Founding member of the SIBC.

Siegfried. Siegfried is a public company, which was founded in 1873, generating sales of CHF 833 million in 2019 with 2200 employees. Siegfried is the second largest CMO in Switzerland for the synthesis of drug substances. Siegfried has nine sites, six in Europe, two in the US, and one in China. The Swiss sites are Evionnaz and the headquarters in Zofingen, with a local production capacity of $350 \mathrm{~m}^{3}$. Siegfried uses enzyme catalysis opportunistically if the desired enzymes are available in the required quantities. Siegfried owns a former BASF site in Minden, Germany with 1458 $\mathrm{m}^{3}$ fermentation volume, in which caffeine, theophylline, ephedrine, and pseudoephedrine were produced by Knoll AG, later BASF. This site has decades of experience with yeast-mediated synthesis of e.g., ephedrine. 
Listing 1. Cont.

Solvias. Private company founded 1999 with headquarters in Basel counting more than 500 employees. Solvias is a provider of integrated solutions in analytical services. In addition, it carries out chemical development including route-scouting services and cGMP custom synthesis of chiral and complex molecules in $\mathrm{kg}$ amounts for clinical trials. The company combines high-throughput experimentation with a catalyst library of more than 500 ligands for heterogenous catalytic transformations for asymmetric hydrogenations, C-X couplings, and asymmetric $\mathrm{C}-\mathrm{C}$ bond formations.

SpiroChem AG. Founded in 2011 as an ETH Zurich spin-off with headquarters in Basel, the company successfully acts as a CRO for drug design and proprietary process chemistry. SpiroChem AG employs 50 FTEs working on high-value-added molecular building blocks for the lead optimization of candidates in drug discovery. Introduction of enzymatic transformations in chemical synthesis routes is not excluded but the current focus is to remain a leader in synthetic chemistry.

SSE. Founded in 1894, the public company Société Suisse des Éxplosifs SA diversified in the early 1970s. SSE invested in a new production unit for fine chemicals and founded Valsynthèse SA in 1983, offering custom pilot and commercial production with hazardous chemical reactions such as nitration or phosgenation $\left(\mathrm{COCl}_{2}\right)$. The SSE group generated sales of CHF 132 million with 650 employees in 2018. The business segment, Fine Chemicals, including the contract manufacturing activities, was recently separated from the explosives business. SSE is a medium-size player among the Swiss CMOs for organic chemicals.

Swissfillon. Swissfillon AG is one of the few Swiss CMOs able to offer aseptic fill and finish with expertise for drug product manufacturing, including primary packaging selection, process development, and secondary packaging for pharmaceutical and biotech companies. Founded in 2013 in Visp (Valais, Switzerland) as a spinoff of the pharma engineering company pixon engineering AG, Swissfillon operates flexible, highly automated, and fully cGMP compliant filling lines for vials, syringes, and cartridges from 11 to 2001 bulk batch size. Swissfillon also has expertise related to regulatory requirements for the drug product in combination with the medical device such as, for example, injectables for ophthalmic applications.

Syngenta. The agro-divisions of Astra Zeneca and Novartis formed the global agrochemistry player Syngenta in 2000. In 2016, ChemChina made a successful takeover offer of USD 43 billion to the Syngenta shareholders, and by summer 2017, ChemChina owned $98 \%$ of Syngenta. In 2020, Syngenta AG, Adama (based in Israel) and the agricultural businesses of Sinochem became a single entity, the Syngenta Group, headquartered in Switzerland, with a turnover of USD 23 billion. In the 2019 annual report, Syngenta AG reported sales of USD 13.6 billion generated with 28,000 employees resulting in an EBITDA (Earnings before interest, taxes, depreciation and amortization) of $22 \%$. Syngenta possesses six sites Switzerland, including the headquarter in Basel, the Monthey site producing crop protection products, the Kaisten site for the production of an herbicide precursor, the Münchwilen site dedicated to development activities, and Stein, one of the three main R\&D sites. Recently, Syngenta's presence in Switzerland was reinforced by the acquisition of a new production site in Muttenz. Syngenta uses biocatalytic methods for discovery, route scouting, and small molecules production. Syngenta is a founding member of the Swiss Industrial Biocatalysis Consortium (SIBC).

SynphaBase. Established in 2000 in Pratteln, SynphaBase is a spin-off of the University of Applied Sciences in Muttenz/Basel. SynphaBase is a custom research and development organization offering route scouting in process chemistry, including multistep synthesis from $\mathrm{mg}$ to metric tons by working with other custom manufacturers. The company uses primarily organic chemical synthesis, although enzymatic catalysis has occasionally been tested to facilitate procedures.

Vifor. The origins of Vifor Pharma date back to 1872. The company grew over the years through merger and acquisition and has several manufacturing sites in Switzerland. Ettingen and Villars-sur-Glâne focus on the manufacture of small molecules while OM Pharma has a focus on biotechnological manufacturing. The site in the canton of Fribourg (Villars-sur-Glâne) offers contract development and manufacturing service for organic chemical synthesis.

VioChemicals. Established in 2001, VioChemicals is a CMO for specialty chemicals, intermediates and APIs produced by chemical synthesis. VioChemicals uses cGMP manufacturing facilities in China and India, while their R\&D center is located in Greece.

\section{Organizations}

CCBIO. Competence center of Biocatalysis of the Zürich Applied University (ZHAW). Establishes biocatalysis as a complementary method to organic synthesis by expanding the biocatalytic toolbox through algorithm- and automation-assisted enzyme engineering and gene mining.

FIT (Farma Industria Ticino). Founded in 1980 as a private organization with 30 member companies, which have a combined workforce of 2900 employees and an annual turnover of CHF 1.7 billion. The organization represents the chemical pharmaceutical industry, which is an important economic pillar in the Swiss canton of Ticino. 
Listing 1. Cont.

SATW. The working group "Biotechnology" of the Swiss Academy of Engineering Sciences focuses on products that are relevant for the Swiss economic space, such as small molecule pharmaceuticals, intermediates, fine chemicals, biochemicals, and other specialties. A joint SBA/SATW initiative currently aims to consolidate the Swiss biotechnology sector.

SBA. Swiss Biotech Association represents the interest of the biotechnology industry, currently predominantly representing the biopharmaceutical industry. A joint SBA/SATW initiative currently aims to consolidate the Swiss biotechnology sector.

SIBC. Swiss Industrial Biocatalysis Consortium was founded in 2004 to help overcome the limitations of applying enzymes in organic synthesis. Current members include Innosyn, Givaudan, Lonza, Merck, Novartis, Roche, and Syngenta. Four associations support the SIBC activities: SBA, scienceindustries, SATW and SKB.

SKB. Swiss Coordination Committee for Biotechnology is an umbrella organization encouraging the development of a sustainable biotechnology sector.

\subsection{Trends and New Advances}

New advances in biocatalysis will be driven by the structural complexity of the products desirable in the flavor, fragrance, and cosmetic industry as well as the pharmaceutical industry. In addition, pressing societal challenges such as the growing importance of sustainable manufacturing, the increasing frequency of drug shortages-whose severity was further accentuated by the supply-chain effects of the COVID-19 crisis-and the lack of novel and effective antibiotics will trigger innovation in the biocatalysis field.

The necessity to develop novel antibiotics to combat the threat posed by (multi)-resistant bacteria has increasingly attracted public awareness leading to the formation of several initiatives such as the "10 $\times 20$ initiative" of the Infectious Disease Society of America (IDSA) [6], founded in 2010, with the goal of finding 10 new antibiotics by 2020. Furthermore, in 2020, a group of 23 global pharmaceutical companies from the US, Europe and Japan created the AMR Action Fund [7] to finance research and development for new drugs combating antibiotic resistance. The goal of the participating companies, which include Swiss companies such as Hoffmann-La Roche AG and Novartis Pharma AG, is to invest US 1 billion to bring two to four new antibiotics to patients by the end of this decade [7].

Another healthcare related issue has begun to trouble Switzerland, and many other European countries during the last decade; namely, an increased frequency of drug shortages. The Federal Office for National Economics maintains a list of drug shortages [8] focusing on vital medicaments. A more comprehensive list of drug shortages in Switzerland is managed by a private initiative [9] and includes all medications that cannot be delivered. A peak was reached November 2019 when 650 drugs were temporarily not available in Switzerland, 140 of which were considered indispensable by the World Health Organization [10], including drugs against high blood pressure, antiepileptic drugs, vaccines for children, generic oncology drugs, and even birth control pills (Table 1).

Not surprisingly, the occurrence of drug shortages has thus already been a topic of a parliamentary initiative, but the discussion was intensified through the amplifying effect of the COVID-19 pandemic when drug shortages were covered by the general and popular media channels. Several relaxant drugs, for example, which were required for the intubation of COVID-19 patients became scarce in Switzerland. In addition, due to panic buying sprees, even non-opioid drugs were at risk of becoming short in supply. Notably, generic drugs were particularly affected, consequently requiring doctors to prescribe drugs that were by orders of magnitude more expensive. In addition, cheap vitamin K1 preparations and other commodities were also periodically not available. 
Table 1. Example of a small selection of drugs, which were periodically not available in Switzerland over the last two years.

\begin{tabular}{|c|c|c|c|}
\hline Product & Application & Structure & Comment \\
\hline Adenine & $\begin{array}{c}\text { Starting material for e.g., } \\
\text { Tenovir }\end{array}$ & & $\begin{array}{l}\text { Periodic shortage resulting in } \\
\text { spiking prices; produced } \\
\text { by fermentation. }\end{array}$ \\
\hline Benzodiazepin & $\begin{array}{l}\text { Psychoactive drug } \\
\text { (sedative, anxiolytic) }\end{array}$ & & $\begin{array}{c}\text { First synthesized by } \\
\text { Hoffmann-La Roche in the } \\
\text { 1950s. }\end{array}$ \\
\hline Dextran & $\begin{array}{c}\text { Treatment of } \\
\text { hypovolemia (decreased } \\
\text { volume of circulating } \\
\text { blood plasma) }\end{array}$ & & $\begin{array}{l}\text { Low molecular dextran or } \\
\alpha \text {-D-1,6- polyisomaltose } \\
\text { produced by fermentation with } \\
\text { Leuconostoc mesenteroides. } \\
\text { A shortage occurred because of } \\
\text { quality issues with cheap } \\
\text { material from India and China. }\end{array}$ \\
\hline Imidazole & $\begin{array}{l}\text { Topical formulations for } \\
\text { fungal infections }\end{array}$ & & - \\
\hline $\begin{array}{l}\text { Levothyroxine } \\
\left(\text { Euthyrox }^{\circledR}\right)\end{array}$ & Thyroid hormone & & - \\
\hline Lamotrigine & Anti-epileptic drug & & Approved since 1993. \\
\hline $\begin{array}{c}\text { Midazolam } \\
\left(\text { Dormicum }{ }^{\circledR}\right)\end{array}$ & Psychoactive drug & & $\begin{array}{l}\text { Short-acting benzodiazepine } \\
\text { derivative with an imidazole } \\
\text { structure. This relaxant is used } \\
\text { during intubations and its } \\
\text { scarcity was a problem during } \\
\text { the first COVID-19 wave } \\
\text { (Midazolam, Remifentanil } \\
\text { and Profol) }\end{array}$ \\
\hline $\begin{array}{l}\text { Mefenamic acid } \\
\quad\left(\text { Ponstan }{ }^{\circledR}\right)\end{array}$ & $\begin{array}{c}\text { Nonsteroidal } \\
\text { anti-inflammatory drug }\end{array}$ & & $\begin{array}{l}\text { Recall because of lead and } \\
\text { lithium impurities found in the } \\
\text { drug formulations. }\end{array}$ \\
\hline $\begin{array}{l}\text { Melphalan } \\
\left(\text { Alkeran }{ }^{\circledR} \text { ) }\right.\end{array}$ & Cytostatic drug & & $\begin{array}{c}\text { Example of an indispensable } \\
\text { drug which was periodically } \\
\text { not available. }\end{array}$ \\
\hline $\begin{array}{l}\text { Paracetamol } \\
\left(\text { Dafalgan }{ }^{\circledR} \text { ) }\right.\end{array}$ & Non-opioid analgesic & & $\begin{array}{l}\text { Panic buying sprees during the } \\
\text { first wave of the COVID-19 } \\
\text { pandemic caused shortages. }\end{array}$ \\
\hline
\end{tabular}


Table 1. Cont

\begin{tabular}{|c|c|c|c|}
\hline Product & Application & Structure & Comment \\
\hline $\begin{array}{l}\text { Piperacillin/ } \\
\text { Tazobactam }\end{array}$ & $\begin{array}{l}\text { Combination of a broad } \\
\text { spectrum } \beta \text {-lactam } \\
\text { antibiotic (top) with a } \\
\beta \text {-lactamase inhibitor } \\
\text { (bottom) }\end{array}$ & & $\begin{array}{l}\text { Semisynthetic ampicillin } \\
\text { derived antibiotic/penicillanic } \\
\text { acid sulfone derivative. } \\
\text { An explosion in a Chinese } \\
\text { factory interrupted supplies. }\end{array}$ \\
\hline Propofol & Parenteral anesthetic & & $\begin{array}{l}\text { Relaxant used for intubations } \\
\text { during the first COVID-19 } \\
\text { pandemic wave. }\end{array}$ \\
\hline Remdesivir & Antiviral & & $\begin{array}{l}\text { ATP analogue; described to } \\
\text { work against Ebola and tested } \\
\text { against the SARS-CoV-2 virus. }\end{array}$ \\
\hline Remifentanil & $\begin{array}{l}\text { Short acting synthetic } \\
\text { opioid analgesic }\end{array}$ & & $\begin{array}{l}\text { Relaxant used for intubations } \\
\text { during the first COVID-19 } \\
\text { pandemic wave. }\end{array}$ \\
\hline Rifampicin & $\begin{array}{l}\text { Broad spectrum } \\
\text { antibiotic }\end{array}$ & & $\begin{array}{l}\text { Semisynthetic antibiotic derived } \\
\text { from Amylatopsis rifamycinia; } \\
\text { macrocyclic antibiotic. }\end{array}$ \\
\hline $\begin{array}{l}\text { Felbamate } \\
\left(\text { Taloxa }{ }^{\circledR}\right)\end{array}$ & Anti-epileptic drug & & - \\
\hline $\begin{array}{l}\text { Lorazepam } \\
\left(\text { Temesta }^{\circledR}\right)\end{array}$ & Sedative & & - \\
\hline
\end{tabular}


Table 1. Cont.

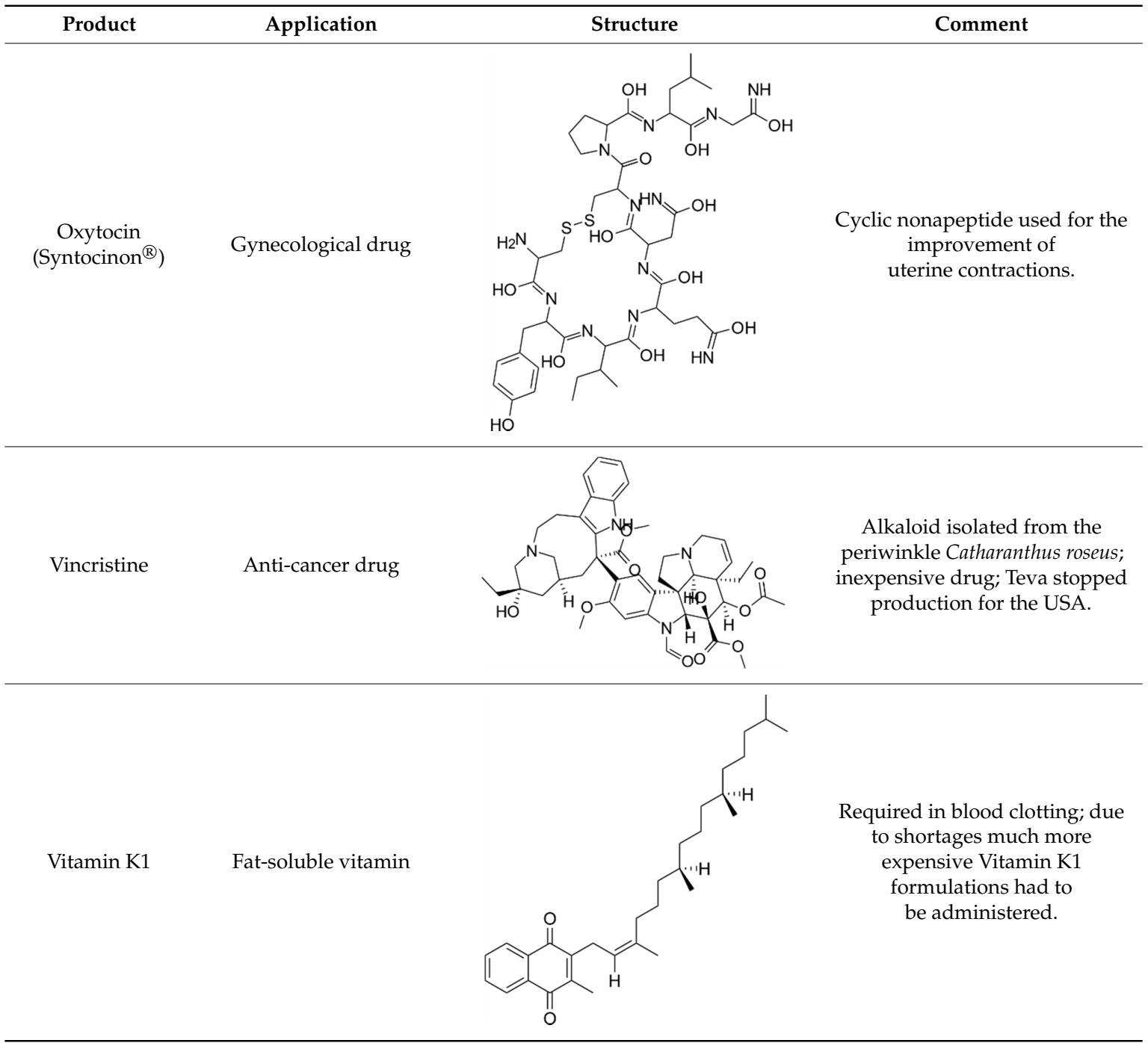

What is at the root of these drug shortages? The main reason can be identified as price pressure requiring cost savings. A common sentiment in society is that "especially drugs of the basic medical care should cost nothing". As a result, the globalized market shifted entire value chains from the West to the East. This triggered a series of events which ultimately led to interrupted supply chains and drug shortages in Switzerland and the world.

- Production relocation of APIs and final formulation to countries with cheap labor, notably China and India. In particular, the production of small molecule APIs and off patent drugs and formulations was affected in this way.

- Pharma companies concentrated their production to a small number of sites in countries with low wages (and often lower environmental standards). The number of production sites was further reduced through mergers and acquisitions.

- The transfer of processes and technologies led to a loss in manufacturing know-how in Western countries.

The restructuring delineated above led to an extremely well organized, just-in-time supply chain miracle, unsurpassed in efficiency. However, accidents, trade conflict, natural disaster or-as the world has recently encountered-pandemics bluntly reveal the weakness of such optimized chains. In addition, a monopolistic supply situation for critical intermediates, for example, of small molecules 
manufactured in China, poses an additional risk. Through this centralized system, single drugs have become sparse, triggered for example by unacceptable impurity profiles in intermediates or by crippling accidents in key factories. The COVID-19 pandemic has accentuated the existing problem. Thus, it comes as no surprise that politicians all over Europe now demand to move back certain value chains.

Bringing back entire production chains, however, is probably best done in a European network. With this in mind, a strategy must be formulated in a way by which Switzerland can best contribute to such an endeavor. State-of-the-art organic chemical synthesis methodologies are very advanced, and chemists are able to predictably synthesize even the most complex molecules-however, often at prohibitive ecologic footprints and at high costs. Challenges, therefore, will include containing costs and assuring sustainable manufacturing, thus requiring considerable process adaptations to meet final price expectations. High automation of the processes could be one way forward. Additionally, a much higher use of biocatalysis in chemical synthesis could help address sustainability issues and introduce novel reactivities.

Today, it is not yet possible to make early route selections and cost estimates for biocatalysis with the same accuracy and reliability as in organic synthesis but first key performance indicators and decision matrices are being formulated [11]. Importantly, despite the increasing application of biopharmaceuticals and gene therapy, we continue to need small molecule drugs to treat diseases. Notably, $50 \%$ of today's drug are derived from natural structures insinuating that using enzymatic synthesis should be at least principally feasible-if not even the preferred manufacturing option for some structures.

\section{Current Status of Biocatalysis}

\subsection{Patenting Activity}

Following up on our former evaluation [2] on the type of enzymes used in biocatalysis reactions (focused on the timespan from 2000 to 2015), we evaluated how the field developed within the last five years. Using SciFinder ${ }^{\circledR}$, we searched for biocatalysis patents that were filed between January 2016 to June 2020 (Figure 1). In the retrieved patent list, we manually identified patents in which an enzyme was described to be employed in a chemical reaction. As a consequence, we excluded patents describing immobilization techniques, optimization of biotechnological processes as well as whole cell biocatalysts and strains without details on the enzymes involved in the reaction. Furthermore, we excluded patents describing applications on waste treatment, detoxifying processes or analytics. Finally, enzymes identified in the patents were assigned to the seven enzyme classes and listed by year, the country the patent was filed, the type of patent applied for, and the patent owner (company or university) (Figure S1).

Notably, the yearly number of biocatalysis patents (clearly stating the type of enzyme involved in biocatalytic process) is still increasing (Figure 1). In addition, our updated analysis confirmed that universities submitted more applications than companies. However, it should be kept in mind that this result might be biased by the fact that companies in some cases prefer "trade secret" over patenting.

Almost 60\% (186/311) of all the patents filed between the beginning of 2016 and June 2020 stem from Chinese universities and companies (Figure 2). This could be due, at least in part, to China's “National Patent Development Strategy (2011-2020)" which was implemented in 2011 to enhance China's core competitiveness [12,13]. Patents filed in Europe accounted for about 25\%, with strongest activities seen in Germany, the UK, and France. 


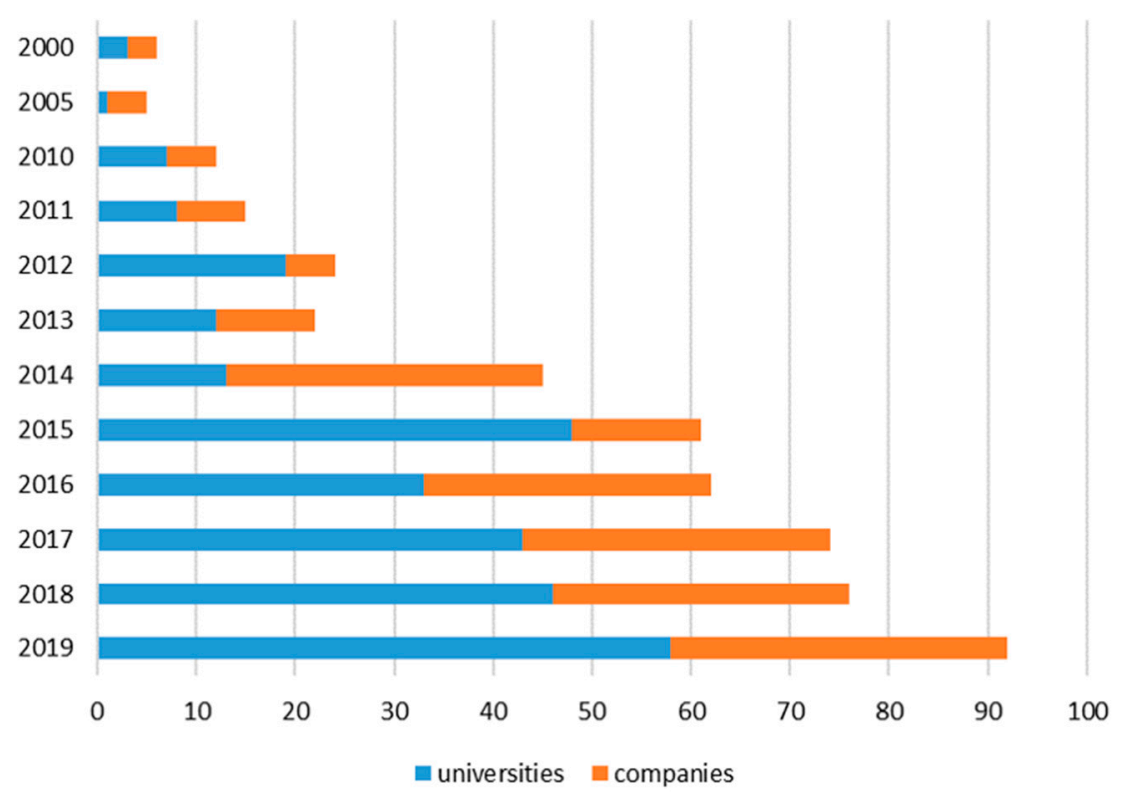

Figure 1. Patents filed by companies or universities from 2000 to June 2019 (including data from [2]).

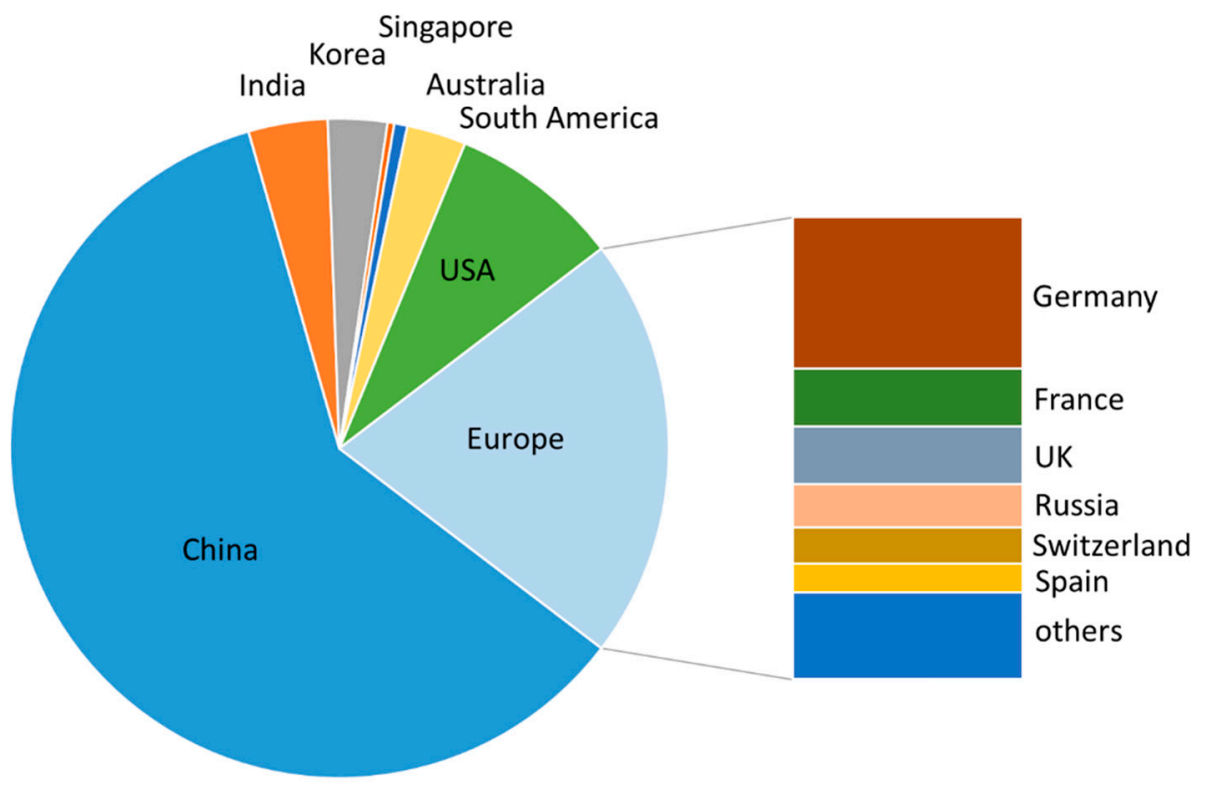

Figure 2. Analysis of country of origin of patents filed between January 2016 and June 2020.

Notably, Chinese patents identified in our search were almost exclusively filed within China, and only five patents have WO status (Figure 3). In contrast, patents filed by other countries mostly have WO status. Patenting activity of Chinese companies as well as academic institution were similarly distributed over the enzyme classes and focused strongly on oxidoreductases (Figure 4). The rest of the world exhibited differences in patenting behavior between companies and academic institutions: whereas companies seem to have an increasing interest in transferases, hydrolases, and lyases, universities show a stronger focus on hydrolases and oxidoreductases (Figure 4). 


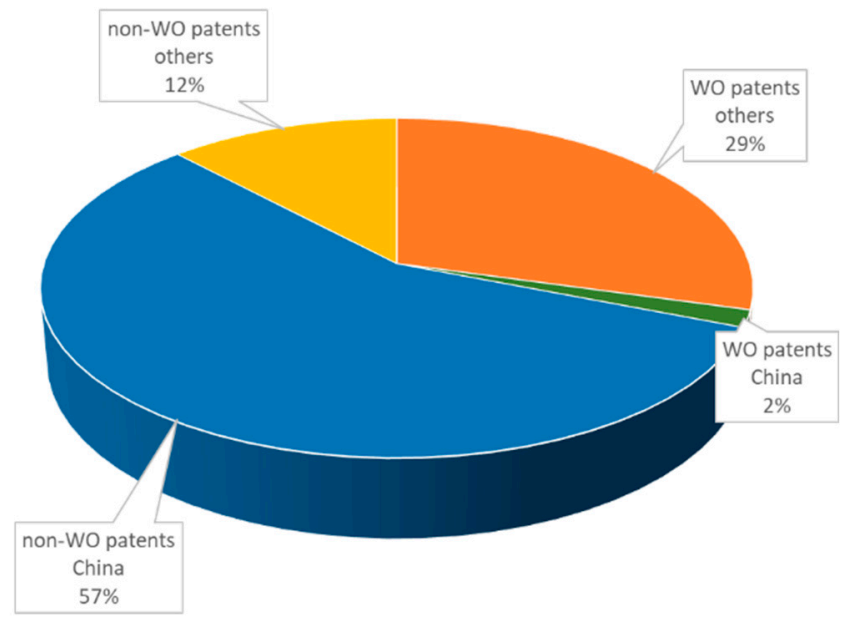

Figure 3. Analysis of type (WO/non-WO) of patents filed between January 2016 and June 2020 in dependence of country.

\section{Companies}

\section{China \\ $(n=191)$ \\ World \\ w/o China \\ $(n=141)$}
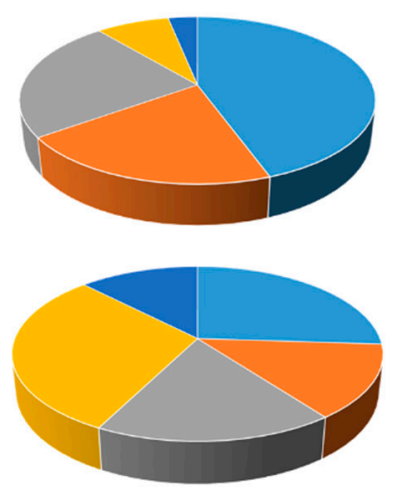

Universities

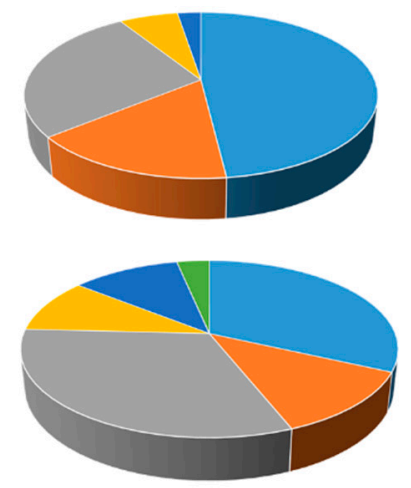

Figure 4. Analysis of enzyme class at the basis of patents filed between January 2016-June 2020.

\subsection{Biocatalytic Trends in Swiss Academic Research}

When analyzing recent research publications in the area of biocatalysis on a global level, a similar trend as for patents emerges. While at the beginning of the century, the USA and Germany were the countries publishing most in the field of biocatalysis, this trend has changed, and in 2019, China published twice as many biocatalysis-related papers than either the USA or Germany (Figure 5). When factoring in the size of the countries, Switzerland's biocatalysis publication activity increased with comparable growth rates to that of Germany.

In Switzerland, biocatalysis is a vibrant field of academic research. Contributions of Swiss universities concentrate on developing new methods and tools such as in the areas of enzyme engineering and development of enzyme toolboxes, high throughput screening, development of biocatalytic in vivo systems, pathway engineering, biocatalyst stabilization, or developing strategies to use sustainable resources. To illustrate areas of interest at Swiss universities, the most recent examples are highlighted in the following paragraph. 


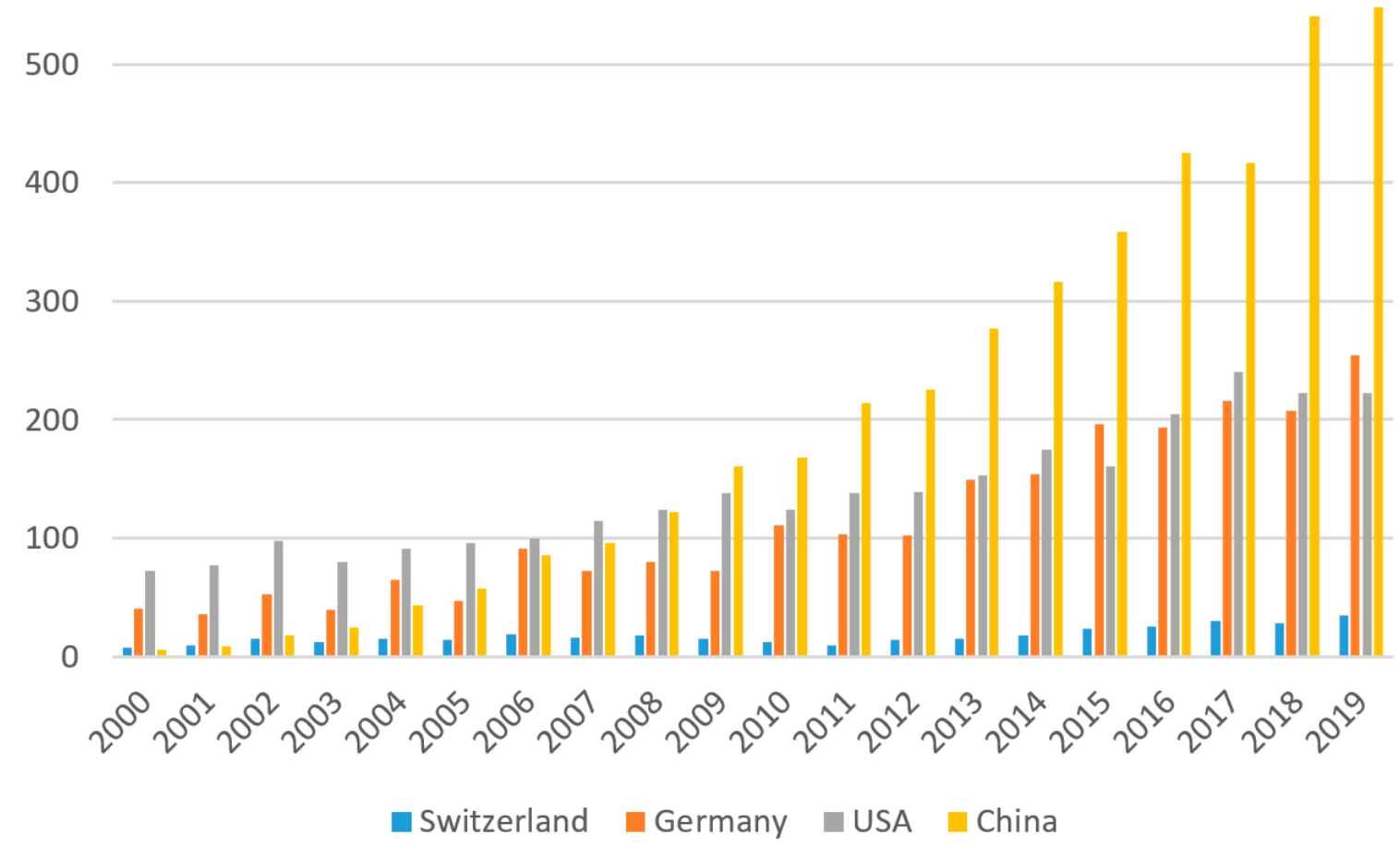

Figure 5. Analysis of the research articles published in the field of biocatalysis between 2000 and 2019. The topic function of Web of Science was searched using the search term "biocatal*". Document types were then restricted to articles, proceeding papers, notes, and letters, the publication date $>2000$, and the respective countries.

\subsubsection{Screening}

Success of enzyme engineering is very much dependent on the efficient screening of libraries. However, this process is often laborious and time consuming, and may require a labelled substrate or product molecule to facilitate read-out. Donald Hilvert and his group (ETHZ) recently established an ultrahigh-throughput label-free microfluidic assay and used it in the efficient remodeling of a cyclohexylamine oxidase [14]. In short, cells from a gene library were injected into a microfluidic chip, mixed with lysis agent, the substrate, and a reporter cascade consisting of horseradish peroxidase and a corresponding fluorogenic substrate. The mixture was compartmentalized into picolitre volume droplets, and cells producing oxidase variants active towards the substrate were separated by fluorescence-activated droplet sorting (FADS). The method identified oxidase variants with up to 960-fold increase in catalytic efficiency for the conversion of the non-natural substrate 1-phenyl-1,2,3,4-tetrahydroisoquinoline, whose (S)-enantiomer is a key precursor of the blockbuster drug solifenacin, in a single evolutionary round.

The group of Sven Panke (ETHZ Basel) recently reported a method for in vivo directed enzyme evolution in nanoliter reactions with anti-metabolite selection [15]. The researchers were interested in producing sulphostin, a dipeptidyl peptidase IV inhibitor and potential type 2 diabetes drug from racemic ornithine. The bottleneck in the synthesis was identified to be the first step catalyzed by a racemase. In vivo selection depends on the ability to evaluate the growth behaviors of different variants from a library. In simple plating experiments, evaluation of large libraries is possible. However, accurately determining often rather subtle changes in growth rates is difficult, as the read-out depends, for example, on plating density, time point of scoring, or metabolic cross talk. Feeding antimetabolites adds additional selectivity to the screening system. In the reported case, first, a fluorescent host auxotrophic for $L$-ornithine was constructed by constitutively over-expressing green fluorescent protein. When feeding $D$-ornithine to this engineered system, bacterial growth was dependent on efficient racemization of $D$-ornithine to $L$-ornithine. Adding $D / L$-lysine as an antimetabolite increased selective 
pressure on the racemase variants. Using optically clear gel-like microcarriers as reaction vessels and fluorescence-assisted particle sorting as read-out for the growth behavior of the library variants, racemase variants with improved catalytic efficiency were isolated.

\subsubsection{Enzyme Cascades}

In order to construct complex molecules, the subsequent action of several enzymes can be required. Within these so-called enzyme cascades, substrates are processed at low steady-state concentrations and ideally no (instable/toxic) intermediates accumulate. In addition, co-substrates or cofactors needed for group-transfer or in redox reactions may be recycled, which reduces operation costs significantly. Realizing the need for biocatalytic methyl transfer, Florian Seebeck and Cangsong Liao (University of Basel) investigated $S$-adenosylhomocysteine as a methyl transfer catalyst in biocatalytic methylation reactions. By constructing enzyme cascades consisting of $\mathrm{C}-, \mathrm{N}-$, and $\mathrm{O}$-specific methyltransferases and halide methyltransferases, the researchers succeeded to carry out biocatalytic methylation reactions in vitro [16]. Notably, the constructed cascades required only catalytic concentrations of $S$-adenosylmethionine (SAM) and used methyl iodide for the stoichiometric methyl donation. Continuing their work [17], the authors reported the asymmetric $\beta$-methylation of $L$-and $D$ - $\alpha$-amino acids by a self-containing enzyme cascade consisting of two reaction cycles running in parallel. The biocatalytic approach involved the oxidation of $\alpha$-amino acid by a stereoselective transaminase (D-TA or L-TA, cofactor PLP) to the corresponding $\alpha$-keto amino acid, which was then stereoselectively methylated by a SAM-dependent $\alpha$-keto amino acid methyltransferase. Finally, the $\alpha$-keto amino acid claims its amino group back from the PMP containing L-TA, recycling PLP. The third enzyme employed in the cascade was a halide methyltransferase which recycled the cofactor SAM from methyl iodide. In contrast to former approaches, the substrate scope of the new method was broadened.

Going one step beyond "conventional" enzyme cascades, Thomas Ward and colleagues (University of Basel, ETHZ-Basel) integrated enzyme cascades with man-made catalysts for the production of cycloalkenes from renewable feedstocks [18]. Cycloalkenes are bulk petrochemicals currently derived from fossil fuels that are industrially used as solvents as well as for the synthesis of cyclic compounds. E. coli cells were engineered to convert dicarboxylic acids or oleic acid to cycloalkenes by a complex enzymatic cascade consisting of up to eight enzymes followed by the final ring-closing metathesis catalyzed by Ru3, a commercially available (Hoveyda)-Grubbs ruthenium(II) catalyst. The group could show that the reactions worked in a one-pot fashion as well as in a consecutive strategy, in which the metal catalyst was added last. By extending the cascade with an upstream hydrolase, olive oil could be employed as the substrate for cycloalkene production.

\subsubsection{Novel Enzyme Toolboxes}

The stereoselective introduction of a halogen atom into a molecular scaffold is synthetically useful for the production of a variety of high-value chemicals such as pharmaceuticals or agrochemicals and can provide a valuable synthetic handle for the further modification of molecules. By engineering $\alpha$-ketoglutarate dependent halogenases, Rebecca Buller and her group (Zurich University of Applied Sciences) reported the first example of expanding the substrate scope of this enzyme family toward a non-native substrate [19]. Martinelline is a potent bradykinin receptor agonist and for some analogs anti-cancer activity has been reported. Starting from the natural halogenase WelO5*, the group evolved enzyme variants for chlorination of a martinelline-derived fragment which showed a 290 -fold higher total turnover number and a 400 -fold higher apparent $k_{\text {cat }}$. In addition, key positions within the active site of the enzyme were identified that can guide the halogen to different position in the target molecule.

\subsubsection{Biopolymers}

Manfred Zinn (HES SO) is elaborating tailor-made biopolymer solutions and manufacturing processes for different markets and applications, for example the microbial production of polyhydroxyalkanoates. A particular focus is set on the elaboration of tailor-made biopolymer 
solutions for industrial (e.g., packaging) and medical applications (e.g., nano-sized drug delivery systems and biocompatible coatings). Tailor-made production of polyhydroxyalkanoates bearing unconventional functional groups in the side chain is of high interest for the control of their mechanical and physical properties. The biocatalytic tailoring of the material properties of polyhydroxyalkanoates (PHAs) is carried out with e.g., lipases to produce block copolymers with novel material properties (melting endotherms and tensile strength) [20]. Such enzymatically catalyzed modifications allow for material specifications required for resorbable implants, tissue engineering, drug delivery or smart materials [21].

\subsubsection{Immobilization and Flow Chemistry}

Addressing manufacturing challenges rooted in insufficient protein stability, Patrick Shahgaldian (University of Applied Sciences ad Arts Northwestern Switzerland) and his group develop strategies to immobilize and shield enzymes by embedding them in an organosilica layer located at the surface of silica particles. When shielding enzymes fully, a possible drawback is that only small substrates are capable of diffusing to the active site of the enzyme. In 2020 [22], the group showed that also partially shielded enzymes possess increased stability and are capable of processing large substrates. The researchers highlighted the applicability of the method by using immobilized sortase for bioconjugation of recombinant monoclonal antibodies or immobilized pepsin for highly specific protein hydrolysis, respectively.

Flow biocatalysis is at the heart of the research carried out by Francesca Paradisi and her group (University of Bern). To increase the efficiency of enzymatic conversions, cell-free biocatalysts are immobilized and loaded in a packed-bed reactor. In a recent application example, the group developed a bi-enzymatic flow biocatalysis approach to produce $L$-pipecolic acid (L-PA) [23]. L-PA is a natural non-proteinogenic $\alpha$-amino acid that is part of many biologically active molecules e.g., natural products with anticancer or antibiotic activity. Another publication highlights the use of flow-based biocatalysis to produce flavor esters [24]. Here, a transferase was immobilized in agar beads and used for flow-based acylation of primary alcohols. Flow biocatalysis increased the overall productivity and avoided enzyme destabilization as well as hydrolysis side-reactions.

\subsection{Biocatalytic Trends in Swiss industrial research}

In the past years, Swiss industrial players have recognized the potential of biocatalysis for the development of fine chemicals and pharmaceuticals as highlighted by the increasing patenting and publishing activity (Figures 1 and 5). Notably, recent research papers including Swiss industrial authors showcase several trends in industrial biocatalysis:

- The use of enzymatic transformations is no longer considered independently but biocatalysis is increasingly being used in concert with organic chemistry and flow chemistry to yield highly productive manufacturing routes.

- The biotechnological production of fine chemicals, specifically in the flavor and fragrance sector, allows the manufacture of complex olfactory molecules.

- In collaboration with academic groups, the exploration of industrially not yet fully established enzyme families allows to broaden the accessible molecular space.

\subsubsection{Combining Biocatalysis with Transition-Metal Catalysis and Flow Chemistry}

The pharmaceutical company F. Hoffmann-La Roche, for example, described the asymmetric synthesis of the serine-threonine kinase inhibitor ipatasertib, intended for the treatment of triple negative metastatic breast cancer [25]. By including two biocatalytic steps and a Ru-catalyzed asymmetric hydrogenation to build the required chiral centers, scientist from Genentech and Roche (Basel) succeeded to develop a process route, in which a bicyclic pyrimidine $\mathbf{1}$ and $\alpha$-aryl- $\beta$-amino acid 2 were efficiently constructed and assembled to yield ipatasertib 3 (Scheme 1). 
<smiles>CC(=O)N(CC(C(=O)O)c1ccc(Cl)cc1)C(C)C(C)N1CCN(c2ncnc3c2[C@@H](C)C[C@@H]3O)CC1</smiles>

Scheme 1. Final assembly of the serine-threonine kinase inhibitor ipatasertib. The chiral centers in the $\alpha$-aryl- $\beta$-amino acid 2 are obtained through two biocatalytic steps.

The biocatalytic transformations enabled to install chirality in the key bicyclic pyrimidine: By embedding a nitrilase-catalyzed resolution and a highly diastereoselective biocatalytic ketone reduction into the reaction sequence, the scientists prevented the production of toxic wastes (iodide) and achieved levels of diastereoselectivity that avoided downstream diastereomeric ratio upgrades and the need to remove metal contaminations. Notably, the forward-looking combination of transition-metal catalysis and biocatalysis in the preparation of the active pharmaceutical ingredient was awarded with the prestigious Sandmeyer award of the Swiss Chemical Society [26].

In another recent process development example, in which biocatalysis was jointly used with transition-metal catalysis and flow chemistry, the pharmaceutical company Novartis developed a process route to produce LCZ696 (4, sacubitril valsartan sodium hydrate), a novel treatment for patients suffering from heart failure (Scheme 2) [27]. While a manufacturing process toward the ingredient valsartan was already established, the production route toward sacubitril needed to be optimized for large-scale manufacture. Due to the anticipated large production volumes, process development efforts focused on the intermediate 7 , which already combined all essential structural and functional elements necessary. Following assembly of intermediate $\mathbf{5}$ via transition-metal catalysis and enabled by flow chemistry, the second chiral center was installed using a transaminase reaction leading to 6 with almost perfect diastereoselectivity. The enzyme CDX-043, a S-selective transaminase obtained by enzyme engineering [28], was used with pyridoxal 5'-phoshate (PLP) as cofactor and isopropylamine as amine donor (Scheme 3). The biotransformation was carried out as a slurry-to-slurry process, since both the substrate 5 and the product $\mathbf{6}$ were poorly soluble in aqueous conditions. Interestingly, the equilibrium of the enzymatic transamination was found to be on the product side-presumably due to the lower solubility of amino acid $\mathbf{6}$ compared to the $\gamma$-ketone acid 5 in the aqueous reaction medium-with conversion of typically $95 \%$, despite carrying out the reaction under atmospheric pressure and employing only a moderate excess of isopropylamine.

In an innovative approach to access the important fragrance compound Ambrox, Swiss F\&F company Givaudan developed a "sesquiterpene-plus-C1" approach utilizing an engineered squalene-hopene cyclase from Alicyclobacillus acidocaldarius in the final cyclization reaction [29]. Starting with $\beta$-farnesene, which is manufactured from sugar by engineered yeast, palladium-catalyzed cyclopropanation followed by E-selective cyclopropyl-carbinyl rearrangement yielded the desired enzyme substrate (E,E-homofarnesol) [30]. 


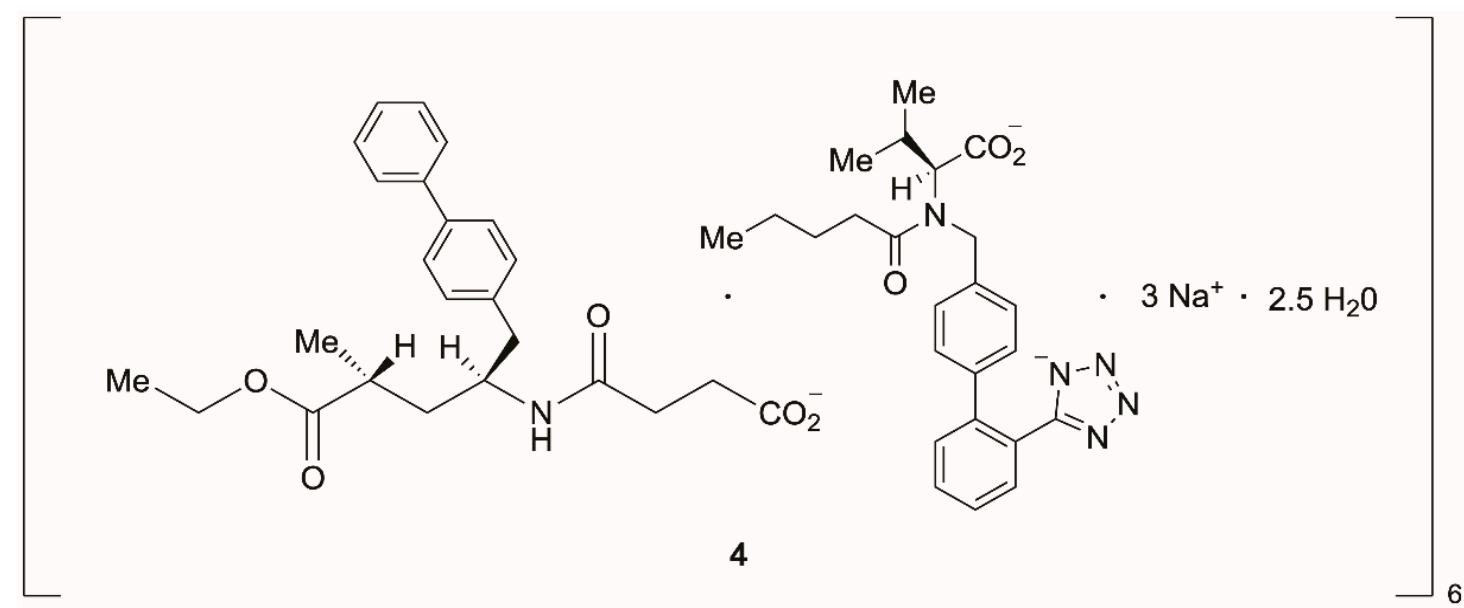

Scheme 2. Structure of LCZ696 (sacubitril valsartan sodium hydrate); structure of sacubitril is shown on the left, structure of valsartan is shown on the right.<smiles>CC(CC(=O)Cc1ccc(-c2ccccc2)cc1)C(=O)[O-]</smiles>

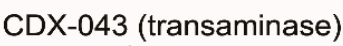
$\mathrm{PLP},{ }^{\mathrm{i}} \mathrm{PrNH}{ }_{2}, \mathrm{HCl}$ $\mathrm{H} 2 \mathrm{O}, \mathrm{pH} 8.5,58^{\circ} \mathrm{C}$<smiles>C[C@H](C[C@@H](N)Cc1ccc(-c2ccccc2)cc1)C(=O)O</smiles><smiles>CO[AsH3]</smiles><smiles>CCOC(=O)[C@H](C)C[C@H](N)Cc1ccc(-c2ccccc2)cc1</smiles>

Scheme 3. Transaminase-driven synthesis of key intermediate 7.

\subsubsection{Producing Fine Chemicals via Biotechnological Means}

In the last decade, flavor and fragrance company Firmenich has implemented several biotechnological routes toward terpene-based fragrance molecules. Complementing its biotechnologically produced ingredients Clearwood ${ }^{\circledR}$ and Ambrox ${ }^{\circledR}$ Super, the company launched a bio-based version of amberketal (Z11) in 2018. For the production of Z11, an industrial fermentation process in yeast was further developed: Following the production of geranylgeranyl diphosphate [31], the introduction of further modifying enzymes allowed to convert the precursor in the relevant terpene (+)-manool, which is the starting material for the powerful compound Amberketal [30].

Similarly targeting the production of bio-based fine chemicals, the company Evolva SA developed yeast as a whole cell biocatalyst for the production of (S)-2-aminobutyric acid and the hitherto purely synthetic compound (S)-2-aminobutanol. The molecules are the enantiomeric precursors for ethambutol, bivaracetam, and levetiraceram, which are anti-tuberculosis and anti-epilepsy drugs, respectively [32]. By designing a two-step heterologous pathway consisting of a Bacillus subtilis 
threonine deaminase and a mutated Escherichia coli glutamate dehydrogenase, the industrial scientists could produce enantiopure (S)-2-aminobutyric acid at levels up to $1.7 \mathrm{mg} / \mathrm{L}$. Addition of three further enzymes, two reductases and a phosphopantetheinyl transferase, to the pathway led to a yeast strain capable of producing (S)-2-aminobutanol at a titer of up to $1.1 \mathrm{mg} / \mathrm{L}$.

\subsubsection{Exploring the Biocatalytic Space}

In a collaboration with the Turner group (Project BIOOX, funded by the European Union's 7th Framework program), Swiss fragrance and flavor company Firmenich looked into the use of an engineered alcohol oxidase for the production of primary aldehydes, which often can be found as components of flavors, fragrances, and food ingredients [33]. Using structure-guided directed evolution of the enzyme cholin oxidase, a FAD-containing biocatalyst, the authors identified an engineered variant that was capable of oxidizing $10 \mathrm{mM}$ hexanol to hexanal in less than $24 \mathrm{~h}$ with $100 \%$ conversion. Overall, this new variant showed increased specific activity for around 50 primary alcohols, including aliphatic, unsaturated, branched, cyclic, benzylic, and halogenated structures. Notably, alcohol oxidases only require oxygen for cofactor recycling in the irreversible oxidation reaction and are thus promising biocatalysts for the oxidation of alcohols. The by-product hydrogen peroxide can be removed via catalases, if necessary.

Exploring the industrially under-represented biocatalytic bond forming reactions, such as $\mathrm{C}-\mathrm{C}$ or C-N bonds, Novartis reported the use of a threonine aldolase to synthesize chiral $\beta$-hydroxy- $\alpha$-amino acids [34]. These compounds are present in many active pharmaceutical intermediates and drug candidates, however, can typically only be accessed by a multistep chemical synthesis. Through in silico gene mining, identification of a threonine aldolases from Vanrija humicola with beneficial catalytic properties was achieved and allowed the scientists to couple a wide range of aldehydes to glycine. By scaling-up a number of enzymatic reactions, the scalability of the biocatalytic process for the asymmetric manufacture of $\beta$-hydroxy- $\alpha$-amino acids was highlighted.

Imine reductases (IREDs), prominently used by Merck in the synthesis LSD1 inhibitor GSK2879552 [35], allow the one-step generation of chiral amines from ketones. Being relatively young players in the field of enzyme catalysis, IREDs have first been reported in 2011 for synthetic applications [36]. Since then, IREDs have been thoroughly studied by a number of groups thanks to their promising synthetic potential [37,38]. In order to broaden the biocatalytic toolbox of available imine reductases, scientists from F. Hoffmann-La Roche built up a toolbox of 28 imine reductases $[39,40]$ and systematically screened these enzymes for reductive amination of ketones. For selected examples such as (1S, 3R)-N,3-dimethylcyclohexylamine and ( $R$ - $N$-methyl-2-aminohexane, the synthesis of the chiral amines was carried out at preparative scale $(100 \mathrm{mg})$ with reasonable yields $(50 \%$ and $55 \%$ ) and excellent stereoselectivities (94\% de and 96\% ee), respectively [40].

The exploration of the biocatalytic space has been very useful for the synthesis of metabolites by a systems biocatalysis approach [41]. Selective enzyme-catalyzed $O$ - and $N$-phosphorylations have been demonstrated as versatile platform technologies and provide various advantages over classical chemical phosphorylations as demonstrated by Sigma-Aldrich/Merck KGaA for the manufacturing of a large variety of phosphorylated metabolites [42-49]. Selective enzymatic water elimination reactions exhibiting full conversion enabled a simple synthetic access to 2-keto-3-deoxysugar acids from easily accessible sugar acids using dehydratases [50-52]. The further extension of ketoreductase-catalyzed reductions of ketones has been first choice in manufacturing the chiral metabolites $(R)$ - and (S)-lactaldehyde [53]. An argininosuccinate lyase-catalyzed Aza-Michael addition reaction of $L$-arginine to fumarate has been successfully used for building the molecule $L$-argininosuccinate in one step from simple starting materials [54]. 


\section{Opportunities}

\subsection{Self-Sustainable Development and Production of Critical Drugs in Developed Countries-Biocatalysis Impact}

The manufacturing and supply chains of approved critical drugs which are routinely used in healthcare systems are operating in a highly dynamic and competitive global economy where production cost considerations are prevailing (vide infra). In the course of the outbreak and global spreading of COVID-19, it became apparent that Switzerland, like any other country, is not self-sustainable in producing critical drugs. Reliable healthcare services and high drug quality are, however, of major importance for a country's society, economy, and well-functioning. Therefore, the adequate consideration of these factors and rebuilding small-footprint and sustainable manufacturing of such approved critical drugs is important in the national and regional context. Pharmaceuticals such as sedatives and anesthetics are essential for intubated patients in intensive care units and backups and emergency supplies of these and other medicines like anti-infectives or vaccines provide not only important products for healthcare but also an opportunity for innovation in reengineering manufacturing routes towards sustainable production systems. The evaluation of the contribution of biocatalysis to the development and production of critical drugs is therefore a worthwhile exercise and will be very valuable for further enzyme applications in drug discovery and development [55].

The dimensions of the challenge can be envisioned from Table 1 showing a small selection of drugs, which are or were periodically not available in Switzerland over the last few years. In the following paragraph, the synthesis of remdesivir, vincristine, and vitamin $\mathrm{K} 1$ will be analyzed and possible contributions of biocatalysis towards their manufacturing will be discussed.

\subsubsection{Remdesivir}

Although no antiviral drugs or vaccines for COVID-19 have been approved, the investigational antiviral prodrug remdesivir, which has been granted an Emergency Use Approval by the FDA and is under-going phase 3 clinical studies, has emerged as viable treatment for COVID-19 patients [56,57]. Therefore, the streamlining and shortening of the time required for manufacturing the final drug, which is effective against SARS-CoV-2, is of key importance. So far, the synthesis of remdesivir, originally discovered to inhibit Ebola virus efficiently and selectively in various cell types, has been achieved by Gilead through various chemical synthesis routes [58,59]. There is, however, room for improvement in various aspects of these described approaches. The key intermediates obtained in the C-glycosylation of the adenine analogue by the protected D-ribono-1,4-lactone have been obtained in relatively low yields. Although the two enzymes currently known to initially activate remdesivir are stereoselective, the $\left(S_{\mathrm{P}}\right)$-diastereomer for remdesivir was selected because of difficulties in synthesizing the required pure $\left(R_{\mathrm{P}}\right)$-diastereomer of the intermediate [60]. Biocatalytic tools have already enabled a novel synthesis of the preferred $R_{P}$-diastereomer of the chiral phosphoramidate precursor using a phosphotriesterase variant from Pseudomonas diminuta [61]. Other chemical reaction steps have been improved, such as the synthesis of the pyrrolotriazine as adenine analogue [62], the C-glycosylation of the pyrrolotriazine by the protected D-ribono-1,4-lactone [63] and the subsequent installation of a quaternary carbon by cyanation [64]. The use of protection-deprotection strategies, hazardous reagents and cryogenic temperatures and the low reported yield, however, still leave room for further improvements. Biocatalytic approaches with high atom economy can be envisioned (Scheme 4) to overcome key challenges in coupling the building blocks of the adenine analogue, the pentose building block derived from ribonolactone and the chiral phosphoramidate precursor to the final C-nucleoside analogue remdesivir. Rethinking the mode of action of remdesivir by synthesizing lipid analogs of the investigational drug could help to make it orally available. The manufacturing of these lipid analogs could also benefit from biocatalytic methods of synthesis [65]. 
<smiles>CCC(CC)OC(=O)[C@H](C)NP(=O)(OC[C@H]1C[C@](O)(c2cc3c(N)ncnn3c2)C[C@H]1O)Oc1ccccc1</smiles><smiles>[R7]P(=O)(N[C@@H](C)C(=O)OC(CC)CC)Oc1ccccc1</smiles><smiles>C=CC=C</smiles>

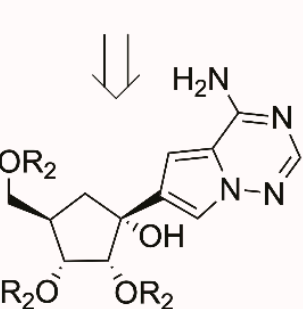

Scheme 4. Retrosynthetic scheme for deconstructing remdesivir to an adenine analogue, the pentose building block, and the phosphoramidate precursor.

\subsubsection{Vincristine}

The clinical supply of vincristine, a drug approved for the treatment of numerous cancers such as acute leukemias, childhood leukemias, and Hodgkin and Non-Hodgkin lymphomas, is hampered by its low abundance in its natural source, the medicinal plant periwinkle (Catharanthus roseus) native to Madagascar [66]. Due to the high clinical demand and encountered supply shortages, various approaches towards vincristine manufacturing have been investigated, including total chemical synthesis [67,68], biosynthesis in plant cell cultures [69], production in transformed root cultures [70], and engineered microbial systems [71]. However, due to a number of bottlenecks and difficulties, production of this complex monoterpene indole alkaloid by the enumerated synthetic methodologies has so far been limited to mg-amounts at best. As the compounds catharanthine and vindoline are more abundant in the plants, semisynthetic approaches using chemical procedures for coupling catharanthine and vindoline to anhydro-vinblastine via the Polonovsky reaction, an Fe(III), or a triarylaminium radical cation-promoted coupling reaction, have been improved over many years to good yields [72-75]. However, such coupling reaction procedures were unsuccessful with $\mathrm{N}$-formyl substituted vindoline. Thus, the chemical synthesis of (+)-vincristine had to proceed via the use of demethylvindoline in the coupling procedure with subsequent conversion of the coupling product to (+)-N-demethyl-vinblastine and final formylation at the N1-position. In vincristine biosynthesis, $\alpha-3^{\prime}, 4^{\prime}$-anhydrovinblastine synthase from Catharanthus roseus has been purified and characterized as the enzyme catalyzing the coupling of catharanthine and vindoline [76]. Whole cell biotransformations 
with Fusarium oxysporum have enabled the conversion of vinblastine to vincristine, although the involved enzymes have not been characterized $[77,78]$. Considering that great progress has been achieved in characterizing almost all of the genes in the plant Catharanthus roseus, which are coding for enzymes involved in vinblastine biosynthesis [79], the opportunities for the development of biocatalytic production procedures of (+)-vincristine look promising (Scheme 5).

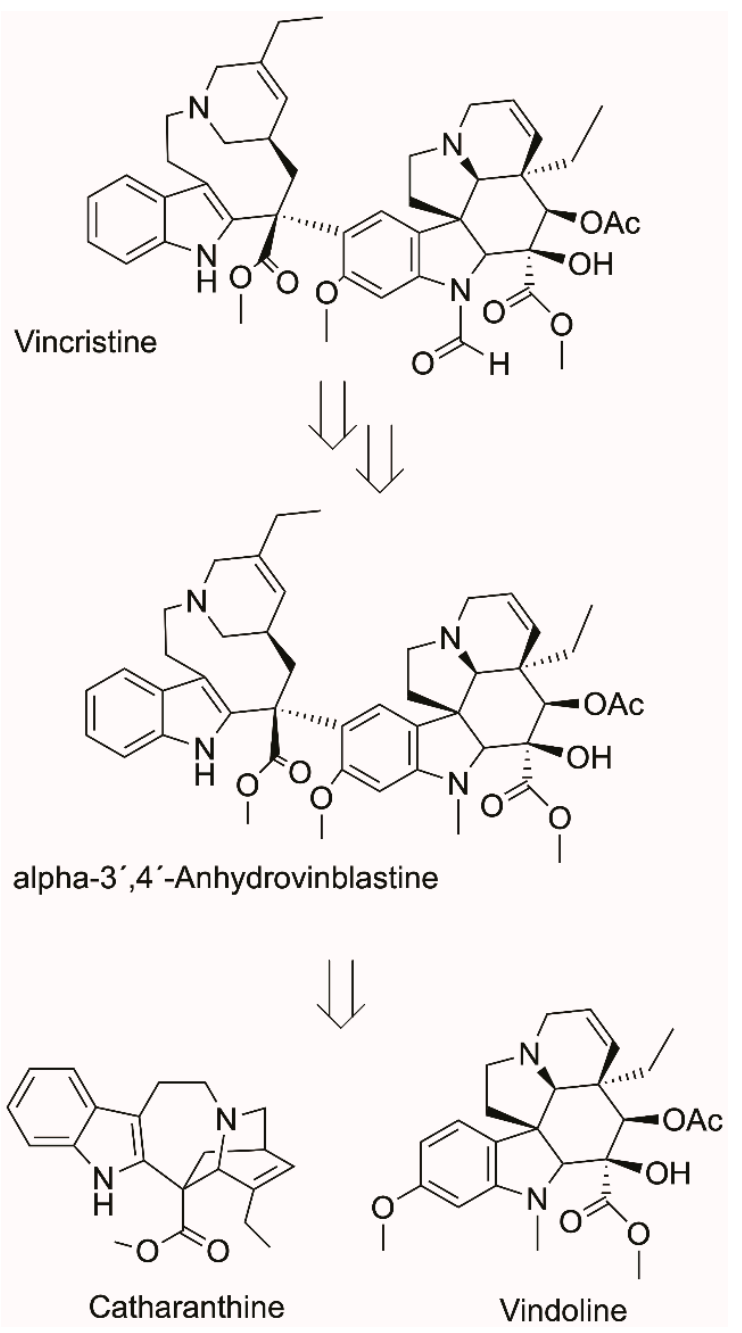

Scheme 5. Retrosynthetic scheme for deconstructing vincristine to the components catharanthine and vindoline.

\subsubsection{Vitamin K1}

Vitamin $\mathrm{K}$ deficiency is at the root of defective coagulation, which can lead to bleeding due to decreased levels of coagulation factors. As a consequence, one of the first medical interventions in human lives is the administering of vitamin $\mathrm{K} 1$ to newborn babies shortly after birth for the prophylaxis and treatment of vitamin $\mathrm{K}$ deficiency. Vitamin $\mathrm{K} 1$, the most prominent among the different vitamin $\mathrm{K}$ structures, also plays a role in bone metabolism, signal transduction, and growth control. An industrial chemical process, starting from the oxidation of 2-methylnaphthalin via the alkylation of menadiol in the 3-position by isophytol, has been implemented. Challenges such as insufficient selectivity of the alkylation step have been overcome by research groups at Roche and Merck KGaA by using monoacylated menadiol $[80,81]$. As the biosynthesis of vitamin K1, also designated as phylloquinone, is known [82], a potential alternative biotechnological approach for manufacturing vitamin $\mathrm{K} 1$ is of much interest [83]. For example, the growth of suitable algal strains, downstream 
processing of the biomass and subsequent vitamin $\mathrm{K} 1$ recovery has been proposed [84]. Although space-time yields of $40 \mu \mathrm{g}$ vitamin $\mathrm{K} 1$ per liter and per day and $0.33 \mathrm{mg}$ per $\mathrm{g}$ biomass have been achieved by cultivating the cyanobacterium Anabaena cylindrica in a bubble column photoreactor, bioproduction of vitamin K1 needs to become more economically competitive [85]. Considering the advantages of cell-free biocatalytic approaches, the short and straightforward biocatalytic synthesis of vitamin $\mathrm{K} 1$ from the inexpensive starting material 1,4-dihydroxynaphthoic acid could be a competitive alternative synthesis route. Following this strategy, manufacturing complexity could be reduced to a two-step biocatalytic synthesis using 1,4-dihydroxy-2-naphthoate phytyltransferase MenA and SAM-dependent demethylphylloquinone methyltransferase MenG in addition to simplifying product recovery (Scheme 6).

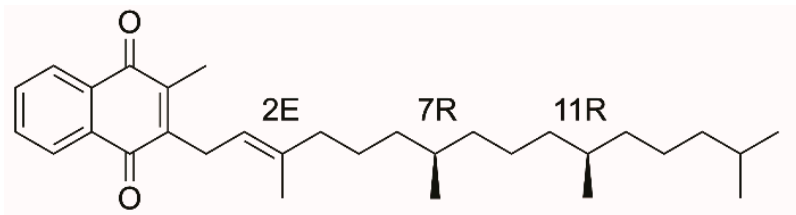

Vitamin K1<smiles>[R]C[C@H](C)CCC[C@@H](C)CCC/C(C)=C/CC1=CC(=O)c2ccccc2C1=O</smiles>

2-Phytyl-1,4-naphthoquinone (PNQ)<smiles>O=C(O)C1=CC(=O)c2ccccc2C1=O</smiles>

2-Carboxy-1,4-naphthoquinone

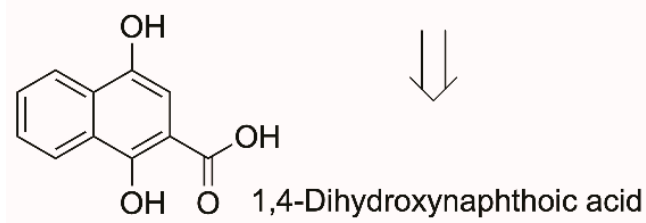<smiles>[R7]CCCC(C)CCCC(C)C(C)CCCC(C)=CCOP(=O)(O)OP(=O)(O)O</smiles>

Phytyl pyrophosphate

Scheme 6. Retrosynthetic scheme for deconstructing vitamin K1 to 1,4-dihydroxynaphthoic acid and phytylpyrophosphate.

\subsection{Collaborations between Industry and Academia and Education}

Biocatalysis, as an interdisciplinary discipline, relies on close collaborations between chemists and biologists. Implementing a new biocatalytic step at industrial scale also requires know-how in process engineering and biotechnology. To promote biocatalysis for the synthesis of small molecules, therefore, several avenues can be followed. In our discussions with academic and industrial representatives of the biocatalysis community in Switzerland the following strategies were recommended: development of new educational concepts, facilitation of close collaborations between academia and industry, publication of success stories highlighting the application of biocatalysts in industrial processes, and, last but not least, a stronger presence of biocatalysis as a discipline in Switzerland. 


\subsubsection{Education in Switzerland}

Biocatalysis is part of the curriculum of most Swiss academic institutes. Detailed teaching content differs and mirrors the discipline hosting the class. Most students are trained while doing a thesis (Bachelor-/Master-/PhD-Thesis) or during a postdoctoral stay within a biocatalysis-focused academic research group. Chemists might focus on reaction mechanisms, biologists on enzyme structure, and process engineers on yields of biocatalysts or final product.

A pure study program "biocatalysis" does not exist within Switzerland. However, an increasing number of interdisciplinary programs with a focus on chemistry and biology have been recently implemented in Switzerland. At the HES-SO Fribourg lectures on enzymes and retrosynthesis were developed for chemistry students and a practical class on biotransformations was introduced at HES-SO Vallais [86]. A "Master in Chemical Biology", a joined effort by the University of Geneva and the EPFL is offered within the NCCR Chemical Biology [87]. The program covers general themes in chemistry, biology, and physics "to exploit the power of chemistry to exploit the progress in biology". At the ETHZ, biologists are introduced to chemical synthesis, methods to analyze and design molecular structures, and molecular/microbiological techniques within the "Major-Biological Chemistry" [88]. In addition, a new "Bachelor in Biochemistry-Chemical Biology" [89] was launched in fall 2020 by the ETH, which will eventually be followed by a master program in fall 2023. The new bachelor's degree program lists basic classes in chemistry and biology in concert with classes in biochemistry, systems biology and biological chemistry, including enzyme evolution. At the Zurich University of Applied Sciences, the course "Industrial Biocatalysis" is taught as part of the Master of Life Sciences program and a "CAS-Biocatalysis" will address the transfer of biocatalysis know-how to post-graduates. The further education course will give a theoretical and practical introduction into biocatalytic reactions, developing and screening biocatalysts, as well as into legal/economic aspects of biocatalytic processes.

\subsubsection{Facilitating Academic-Industrial Collaborations}

In Switzerland, there are several initiatives that allow us to evaluate biocatalytic approaches between academic institutions and industrial partners. Innosuisse (Swiss Agency for Innovation Promotion) supports collaborations between industrial and academic partners in Switzerland [90]. Within the new "Flagship Initiative", which will be launched in early 2021, transdisciplinary project collaborations between industrial-academic consortia will be funded. BRIDGE, a joint program between Innosuisse and the Swiss National Science Foundation (SNSF), funds projects at the interface between basic research and science-based innovation that aim to develop an application or service and plan to explore and implement the research [91]. Going forward, it will be key to also develop and offer precompetitive programs that facilitate the exchange between academic and industrial partners from an even earlier stage, similar to the Swiss network program, "Innovation in Biocatalysis" [86]. In this way, the partners explore innovations with the potential to both impact fundamental science and "real world" application.

\section{Conclusions}

The application of enzymes has developed from traditional knowledge and experience in various areas towards specialized manufacturing methodologies in industrial sectors such as the food and drink industries, chemical and pharmaceutical industries, agrochemical industry, detergent, household and personal care industries, cosmetics industry, as well as the flavor and fragrance industry. Switzerland has a long tradition of enzyme applications and with the tremendous advances in sequencing, information and communication technologies and the growth of knowledge about the structure-function relationships of enzymes, biocatalytic approaches are adopted more and more frequently in industrial settings in Switzerland and globally.

In summary, we do acknowledge that there remain hurdles to the widespread adoption of biocatalysis. However, by having probed the state of mind of Swiss companies and academics as well 
as having analyzed global research and patent trends, we feel confident that the accelerating scientific progress in Switzerland and elsewhere will continue to fuel the implementation of biocatalysis in industry and will open up avenues for cost-effective and sustainable manufacturing. The currently ongoing global COVID-19 pandemic reminds us of the importance of long-term commitment to fundamental and applied sciences in the area of infectious diseases [92,93]. As very high investments into research and development are required to discover and develop novel pharmaceuticals for effective treatment of diseases, joint efforts by science, industry, and society are needed. Their subsequent translation into robust and resilient manufacturing and supply chains and the early consideration of safety, health, environment, and sustainability issues in manufacturing routes is highly important as well. Building bridges across scientific disciplines such as chemistry and biotechnology, but also between academia and industry and between short-term and long-term goals in Switzerland have been key success factors in the past [94] and will continue to be valuable for the present and future. As biocatalysis is a key enabling technology [95] and offers numerous opportunities for streamlining manufacturing routes that are not sufficiently resource-efficient, the reengineering of synthetic routes for chemical pharmaceutical production in Switzerland towards bio-based value chains is an ambitious but valuable goal for Switzerland and its major economic partner countries from the European Union.

Supplementary Materials: The following are available online at http://www.mdpi.com/2073-4344/10/12/1420/s1. Figure S1: Patent Search Strategy.

Author Contributions: Conceptualization: H.-P.M., R.W., K.H., R.B.; writing H.-P.M., R.W., K.H., R.B. All authors have read and agreed to the published version of the manuscript.

Funding: This work was supported by the Swiss State Secretariat for Education, Research and Innovation (Federal project contributions 2017-2020, P-14: Innovation in Biocatalysis).

Acknowledgments: Open Access Funding by Zurich University of Applied Sciences (ZHAW).

Conflicts of Interest: The authors declare no conflict of interest.

\section{References}

1. Switzerland Seen as Top Test Market for Europe. Available online: https://www.swissinfo.ch/eng/switzerlandseen-as-top-test-market-for-europe/3039956 (accessed on 11 November 2020).

2. Buller, R.H.K.; Mirata, M.; Meyer, H.-P. An appreciation of Biocatalysis in the Swiss Manufacturing Environment. In Biocatalysis: An Industrial Perspective; de Gonzalo, G., Domínguez de Maria, P., Eds.; Royal Society of Chemistry: Cambridge, UK, 2018; pp. 1-43.

3. Swiss Biotech Report 2020. Available online: https://www.swissbiotech.org/report/ (accessed on 21 August 2020).

4. The Importance of the Pharmaceutical Industry for Switzerland. Available online: https://www.bak-economics. com/fileadmin/documents/reports/BAK_Economics_Polynomics_Interpharma_Bedeutungsstudie_e.pdf (accessed on 28 August 2020).

5. Meyer, H.P.; Werbitzky, O. Development of Swiss Biotechnology Beyond the Biopharmaceutical Sector. In memoriam Prof. Dr. Oreste Ghisalba (1946-2018). Chimia 2020, 74, 345-359. [CrossRef] [PubMed]

6. Antibiotic Development: The $10 \times 20$ Initiative. Available online: https://www.idsocety.org; https://www. idsociety.org/policy--advocacy/antimicrobial-resistance/antibiotic-development-the-10-x-20-initiative/ (accessed on 28 August 2020).

7. AMR Action Fund. Available online: https://amractionfund.com/ (accessed on 4 September 2020).

8. Reporting Federal Office for National Economic Supply FONES. Available online: https://www.bwl.admin. ch/bwl/en/home/themen/heilmittel/meldestelle.html (accessed on 2 December 2020).

9. Drugshortage.ch. Available online: https://www.drugshortage.ch/ (accessed on 31 July 2020).

10. WHO Model Lists of Essential Medicines. Available online: https://www.who.int/groups/expert-committeeon-selection-and-use-of-essential-medicines/essential-medicines-lists (accessed on 13 November 2020).

11. $11 \mathrm{Wu}$, S.; Snajdrova, R.; Moore, J.C.; Baldenius, K.; Bornscheuer, U.T. Biocatalysis: Enzymatic Synthesis for Industrial Applications. Angew. Chem. Int. Ed. 2020, 59, 2-54. [CrossRef] 
12. Prud'homme, D. China's shifting patent landscape and State-led patenting strategy. J. Intellect. Prop. Law Pract. 2015, 10, 619-625. [CrossRef]

13. Notice of the State Intellectual Property Office on Issuing the National Patent Development Strategy (2011-2020). Available online: http://www.lawinfochina.com/Display.aspx?Lib=law\&Id=8611\&keyword (accessed on 20 November 2020).

14. Debon, A.; Pott, M.; Obexer, R.; Green, A.P.; Friedrich, L.; Griffiths, A.D.; Hilvert, D. Ultrahigh-throughput screening enables efficient single-round oxidase remodelling. Nat. Catal. 2019, 2, 740-747. [CrossRef]

15. Femmer, C.; Bechtold, M.; Held, M.; Panke, S. In vivo directed enzyme evolution in nanoliter reactors with antimetabolite selection. Metab. Eng. 2020, 59, 15-23. [CrossRef]

16. Liao, C.S.; Seebeck, F.P. S-adenosylhomocysteine as a methyl transfer catalyst in biocatalytic methylation reactions. Nat. Catal. 2019, 2, 696-701. [CrossRef]

17. Liao, C.S.; Seebeck, F.P. Asymmetric beta-Methylation of L- and D-alpha-Amino Acids by a Self-Contained Enzyme Cascade. Angew. Chem. Int. Ed. 2020, 59, 7184-7187. [CrossRef]

18. Wu, S.K.; Zhou, Y.; Gerngross, D.; Jeschek, M.; Ward, T.R. Chemo-enzymatic cascades to produce cycloalkenes from bio-based resources. Nat. Commun. 2019, 10, 5060:1-5060:9. [CrossRef]

19. Hayashi, T.; Ligibel, M.; Sager, E.; Voss, M.; Hunziker, J.; Schroer, K.; Snajdrova, R.; Buller, R. Evolved Aliphatic Halogenases Enable Regiocomplementary C-H Functionalization of Pharmaceutically Relevant. Angew. Chem. Int. Ed. 2019, 58, 18535-18539. [CrossRef]

20. Amstutz, V.; Hanik, N.; Pott, J.; Utsunomia, C.; Zinn, M. Tailored biosynthesis of polyhydroxyalkanoates in chemostat cultures. In Enzymatic Polymerizations; Bruns, N., Loos, K., Eds.; Academic Press Ltd.-Elsevier Science Ltd.: London, UK, 2019; Volume 627, pp. 99-123.

21. Hanik, N.; Utsunomia, C.; Guebitz, G.; Zinn, M. All about blocks... and copolymers thereof-Current and future playgrounds for polyhydroxyalkanoates. New Biotechnol. 2018, 44, S106. [CrossRef]

22. Briand, M.L.; Gebleux, R.; Richina, F.; Correro, M.R.; Grether, Y.; Dudal, Y.; Braga-Lagache, S.; Heller, M.; Beerli, R.R.; Grawunder, U.; et al. Partially shielded enzymes capable of processing large protein substrates. Chem. Commun. 2020, 56, 5170-5173. [CrossRef] [PubMed]

23. Padrosa, D.R.; Benitez-Mateos, A.I.; Calvey, L.; Paradisi, F. Cell-free biocatalytic syntheses of L-pipecolic acid: A dual strategy approach and process intensification in flow. Green Chem. 2020, 22, 5310-5316. [CrossRef]

24. Contente, M.L.; Tamborini, L.; Molinari, F.; Paradisi, F. Aromas flow: Eco-friendly, continuous, and scalable preparation of flavour esters. J. Flow Chem. 2020, 10, 235-240. [CrossRef]

25. Han, C.; Savage, S.; Al-Sayah, M.; Yajima, H.; Remarchuk, T.; Reents, R.; Wirz, B.; Iding, H.; Bachmann, S.; Fantasia, S.M.; et al. Asymmetric Synthesis of Akt Kinase Inhibitor Ipatasertib. Org. Lett. 2017, 19, 4806-4809. [CrossRef]

26. Swiss Chemical Society. Available online: https://polycoll.ch/index.php?option=com_content\&view= category\&layout=blog\&id=91\&Itemid=590\&lang=en (accessed on 2 December 2020).

27. Gu, X.; Zhao, J.; Chen, L.; Li, Y.; Yu, B.; Tian, X.; Min, Z.; Xu, S.; Gu, H.; Sun, J.; et al. Application of Transition-Metal Catalysis, Biocatalysis, and Flow Chemistry as State-of-the-Art Technologies in the Synthesis of LCZ696. J. Org. Chem. 2020, 85, 6844-6853. [CrossRef]

28. Novick, S.J.; Dellas, N.; Alvizo, O.; Garcia, R.D.; Ching, C.; Entwistle, D. Engineered Transaminase Polypeptides for Industrial Biocatalysis. U.S. Patent No. WO 2018/231462 A1, 20 December 2018.

29. Eichhorn, E.; Locher, E.; Guillemer, S.; Wahler, D.; Fourage, L.; Schilling, B. Biocatalytic Process for (-)-Ambrox Production Using Squalene Hopene Cyclase. Adv. Synth. Catal. 2018, 360, 2339-2351. [CrossRef]

30. Armanino, N.; Charpentier, J.; Flachsmann, F.; Goeke, A.; Liniger, M.; Kraft, P. What's Hot, What's Not: The Trends of the Past 20 Years in the Chemistry of Odorants. Angew. Chem. Int. Ed. 2020, 59, 16310-16344. [CrossRef]

31. Schalk, M.; Pastore, L.; Mirata, M.A.; Khim, S.; Schouwey, M.; Deguerry, F.; Pineda, V.; Rocci, L.; Daviet, L. Toward a Biosynthetic Route to Sclareol and Amber Odorants. J. Am. Chem. Soc. 2012, 134, 18900-18903. [CrossRef]

32. Weber, N.; Hatsch, A.; Labagnere, L.; Heider, H. Production of (S)-2-aminobutyric acid and (S)-2-aminobutanol in Saccharomyces cerevisiae. Microb. Cell Fact. 2017, 16, 51:1-51:17. [CrossRef]

33. Heath, R.S.; Birmingham, W.R.; Thompson, M.P.; Taglieber, A.; Daviet, L.; Turner, N.J. An Engineered Alcohol Oxidase for the Oxidation of Primary Alcohols. ChemBioChem 2019, 20, 276-281. [CrossRef] 
34. Ligibel, M.; Moore, C.; Bruccoleri, R.; Snajdrova, R. Identification and application of threonine aldolase for synthesis of valuable alpha-amino, beta-hydroxy-building blocks. Biochim. Biophys. Acta-Proteins Proteom. 2020, 1868, 140323:1-140323:8. [CrossRef]

35. Schober, M.; MacDermaid, C.; Ollis, A.A.; Chang, S.; Khan, D.; Hosford, J.; Latham, J.; Ihnken, L.A.F.; Brown, M.J.B.; Fuerst, D.; et al. Chiral synthesis of LSD1 inhibitor GSK2879552 enabled by directed evolution of an imine reductase. Nat. Catal. 2019, 2, 909-915. [CrossRef]

36. Mitsukura, K.; Suzuki, M.; Shinoda, S.; Kuramoto, T.; Yoshida, T.; Nagasawa, T. Purification and Characterization of a Novel (R)-Imine Reductase from Streptomyces sp. GF3587. Biosci. Biotechnol. Biochem. 2011, 75, 1778-1782. [CrossRef] [PubMed]

37. Grogan, G.; Turner, N.J. InspIRED by Nature: NADPH-Dependent Imine Reductases (IREDs) as Catalysts for the Preparation of Chiral Amines. Chem. Eur. J. 2016, 22, 1900-1907. [CrossRef]

38. Grogan, G. Synthesis of chiral amines using redox biocatalysis. Curr. Opin. Chem. Biol. 2018, 43, 15-22. [CrossRef] [PubMed]

39. Wetzl, D.; Berrera, M.; Sandon, N.; Fishlock, D.; Ebeling, M.; Müller, M.; Hanlon, S.; Wirz, B.; Iding, H. Expanding the Imine Reductase Toolbox by Exploring the Bacterial Protein-Sequence Space. ChemBioChem 2015, 16, 1749-1756. [CrossRef]

40. Wetzl, D.; Gand, M.; Ross, A.; Müller, H.; Matzel, P.; Hanlon, S.P.; Müller, M.; Wirz, B.; Höhne, M.; Iding, H. Asymmetric Reductive Amination of Ketones Catalyzed by Imine Reductases. ChemCatChem 2016, 8, 2023-2026. [CrossRef]

41. Wohlgemuth, R. Horizons of Systems Biocatalysis and Renaissance of Metabolite Synthesis. Biotechnol. J. 2018, 13, 1700620:1-1700620:14. [CrossRef]

42. Gauss, D.; Schönenberger, B.; Molla, G.S.; Kinfu, B.M.; Chow, J.; Liese, A.; Streit, W.R.; Wohlgemuth, R. Biocatalytic Phosphorylation of Metabolites. In Applied Biocatalysis: From Fundamental Science to Industrial Applications; Hilterhaus, L., Liese, A., Kettling, U., Antranikian, G., Eds.; Wiley-VCH Verlag GmbH \& Co. KGaA: Weinheim, Germany, 2016; pp. 147-177. [CrossRef]

43. Hardt, N.; Kinfu, B.M.; Chow, J.; Schoenenberger, B.; Streit, W.R.; Obkircher, M.; Wohlgemuth, R. Biocatalytic Asymmetric Phosphorylation Catalyzed by Recombinant Glycerate-2-Kinase. ChemBioChem 2017, 18, 1518-1522. [CrossRef]

44. Matsumi, R.; Hellriegel, C.; Schoenenberger, B.; Milesi, T.; van der Oost, J.; Wohlgemuth, R. Biocatalytic asymmetric phosphorylation of mevalonate. RSC Adv. 2014, 4, 12989-12994. [CrossRef]

45. Schoenenberger, B.; Wszolek, A.; Milesi, T.; Brundiek, H.; Obkircher, M.; Wohlgemuth, R. Synthesis of N-omega-Phospho-(L)-arginine by Biocatalytic Phosphorylation of (L)-Arginine. ChemCatChem 2017, 9, 121-126. [CrossRef]

46. Schoenenberger, B.; Wszolek, A.; Meier, R.; Brundiek, H.; Obkircher, M.; Wohlgemuth, R. Recombinant AroL-Catalyzed Phosphorylation for the Efficient Synthesis of Shikimic Acid 3-Phosphate. Biotechnol. J. 2018, 13, 1700529:1-1700529:8. [CrossRef] [PubMed]

47. Gauss, D.; Sanchez-Moreno, I.; Oroz-Guinea, I.; Garcia-Junceda, E.; Wohlgemuth, R. Phosphorylation Catalyzed by Dihydroxyacetone Kinase. Eur. J. Org. Chem. 2018, 23, 2892-2895. [CrossRef]

48. Wohlgemuth, R.; Liese, A.; Streit, W. Biocatalytic Phosphorylations of Metabolites: Past, Present, and Future. Trends Biotechnol. 2017, 35, 452-465. [CrossRef]

49. Wohlgemuth, R. Key advances in biocatalytic phosphorylations in the last two decades-Biocatalytic syntheses in vitro and biotransformations in-vivo (in humans). Biotechnol. J. 2020, in press. [CrossRef]

50. Matsubara, K.; Koehling, R.; Schoenenberger, B.; Kouril, T.; Esser, D.; Braesen, C.; Siebers, B.; Wohlgemuth, R. One-step synthesis of 2-keto-3-deoxy-D-gluconate by biocatalytic dehydration of D-gluconate. J. Biotechnol. 2014, 191, 69-77. [CrossRef]

51. Krevet, S.; Shen, L.; Bohnen, T.; Schoenenberger, B.; Meier, R.; Obkircher, M.; Bangert, K.; Koehling, R.; Allenspach, E.; Wohlgemuth, R.; et al. Enzymatic Synthesis of 2-Keto-3-Deoxy-6-Phosphogluconate by the 6-Phosphogluconate-Dehydratase From Caulobacter crescentus. Front. Bioeng. Biotechnol. 2020, 8, 185:1-185:10. [CrossRef]

52. Shen, L.; Kohlhaas, M.; Enoki, J.; Meier, R.; Schoenenberger, B.; Wohlgemuth, R.; Kourist, R.; Niemeyer, F.; van Niekerk, D.; Braesen, C.; et al. A combined experimental and modelling approach for the Weimberg pathway optimisation. Nat. Commun. 2020, 11, 1098:1-1098:13. [CrossRef] 
53. Vogel, M.A.K.; Burger, H.; Schlager, N.; Meier, R.; Schonenberger, B.; Bisschops, T.; Wohlgemuth, R. Highly efficient and scalable chemoenzymatic syntheses of (R)- and (S)-lactaldehydes. React. Chem. Eng. 2016, 1, 156-160. [CrossRef]

54. Schoenenberger, B.; Wszolek, A.; Meier, R.; Brundiek, H.; Obkircher, M.; Wohlgemuth, R. Biocatalytic asymmetric Michael addition reaction of L-arginine to fumarate for the green synthesis of $\mathrm{N}-(((4 \mathrm{~S})-4$-amino-4-carboxy-butyl amino) iminomethyl)-L-aspartic acid lithium salt (L-argininosuccinic acid lithium salt). RSC Adv. 2017, 7, 48952-48957. [CrossRef]

55. Fryszkowska, A.; Devine, P.N. Biocatalysis in drug discovery and development. Curr. Opin. Chem. Biol. 2020, 55, 151-160. [CrossRef] [PubMed]

56. Beigel, J.H.; Tomashek, K.M.; Dodd, L.E.; Mehta, A.K.; Zingman, B.S.; Kalil, A.C.; Hohmann, E.; Chu, H.Y.; Luetkemeyer, A.; Kline, S.; et al. Remdesivir for the Treatment of Covid-19-Final Report. N. Eng. J. Med. 2020, 383, 1813-1826. [CrossRef] [PubMed]

57. Coronavirus (COVID-19) Update: FDA Issues Emergency Use Authorization for Potential COVID-19 Treatment. Available online: https:/www.fda.gov/news-events/press-announcements/coronaviruscovid-19-update-fda-issues-emergency-use-authorization-potential-covid-19-treatment (accessed on 10 November 2020).

58. Warren, T.K.; Jordan, R.; Lo, M.K.; Ray, A.S.; Mackman, R.L.; Soloveva, V.; Siegel, D.; Perron, M.; Bannister, R.; Hui, H.C.; et al. Therapeutic efficacy of the small molecule GS-5734 against Ebola virus in rhesus monkeys. Nature 2016, 531, 381-385. [CrossRef]

59. Al Bujuq, N. Methods of Synthesis of Remdesivir, Favipiravir, Hydroxychloroquine, and Chloroquine: Four Small Molecules Repurposed for Clinical Trials during the Covid-19 Pandemic. Synthesis-Stuttgart 2020, 52, 3735-3750. [CrossRef]

60. Liang, C.; Tian, L.; Liu, Y.; Hui, N.; Qiao, G.; Li, H.; Shi, Z.; Tang, Y.; Zhang, D.; Xie, X.; et al. A promising antiviral candidate drug for the COVID-19 pandemic: A mini-review of remdesivir. Eur. J. Med. Chem. 2020, 201, 112527:1-112527:15. [CrossRef] [PubMed]

61. Bigley, A.N.; Narindoshvili, T.; Raushel, F.M. A Chemoenzymatic Synthesis of the $\left(R_{P}\right)$-Isomer of the Antiviral Prodrug Remdesivir. Biochemistry 2020, 59, 3038-3043. [CrossRef] [PubMed]

62. Paymode, D.J.; Cardoso, F.S.P.; Agrawal, T.; Tomlin, J.W.; Cook, D.W.; Burns, J.M.; Stringham, R.W.; Sieber, J.D.; Gupton, B.F.; Snead, D.R. Expanding Access to Remdesivir via an Improved Pyrrolotriazine Synthesis: Supply Centered Synthesis. Org. Lett. 2020, 22, 7656-7661. [CrossRef]

63. Xue, F.; Zhou, X.; Zhou, R.; Zhou, X.; Xiao, D.; Gu, E.; Guo, X.; Xiang, J.; Wang, K.; Yang, L.; et al. Improvement of the C-glycosylation Step for the Synthesis of Remdesivir. Org. Process Res. Dev. 2020, 24, 1772-1777. [CrossRef]

64. Vieira, T.; Stevens, A.C.; Chtchemelinine, A.; Gao, D.; Badalov, P.; Heumann, L. Development of a Large-Scale Cyanation Process Using Continuous Flow Chemistry En Route to the Synthesis of Remdesivir. Org. Process Res. Dev. 2020, 24, 2113-2121. [CrossRef]

65. Schooley, R.T.; Carlin, A.F.; Beadle, J.R.; Valiaeva, N.; Zhang, X.-Q.; Garretson, A.F.; Smith, V.I.; Murphy, J.; Hostetler, K.Y. Rethinking Remdesivir: Synthesis of Lipid Prodrugs that Substantially Enhance Anti-Coronavirus Activity. bioRxiv 2020. [CrossRef]

66. Kumar, A. Vincristine and vinblastine: A review. Int. J. Med. Pharm. Sci. 2016, 6, 23-30.

67. Kuboyama, T.; Yokoshima, S.; Tokuyama, H.; Fukuyama, T. Stereocontrolled total synthesis of (+)-vincristine. Proc. Nat. Acad. Sci. USA 2004, 101, 11966-11970. [CrossRef] [PubMed]

68. Ishikawa, H.; Colby, D.A.; Seto, S.; Va, P.; Tam, A.; Kakei, H.; Rayl, T.J.; Hwang, I.; Boger, D.L. Total Synthesis of Vinblastine, Vincristine, Related Natural Products, and Key Structural Analogues. J. Am. Chem. Soc. 2009, 131, 4904-4916. [CrossRef]

69. Arya, S.S.; Rookes, J.E.; Cahill, D.M.; Lenka, S.K. Next-generation metabolic engineering approaches towards development of plant cell suspension cultures as specialized metabolite producing biofactories. Biotechnol. Adv. 2020, 45, 107635:1-107635:19. [CrossRef] [PubMed]

70. Shi, M.; Liao, P.; Nile, S.H.; Georgiev, M.I.; Kai, G. Biotechnological Exploration of Transformed Root Culture for Value-Added Products. Trends in Biotechnol. 2020, in press. [CrossRef] [PubMed]

71. Casini, A.; Chang, F.-Y.; Eluere, R.; King, A.M.; Young, E.M.; Dudley, Q.M.; Karim, A.; Pratt, K.; Bristol, C.; Forget, A.; et al. A Pressure Test to Make 10 Molecules in 90 Days: External Evaluation of Methods to Engineer Biology. J. Am. Chem. Soc. 2018, 140, 4302-4316. [CrossRef] 
72. Langlois, N.; Gueritte, F.; Langlois, Y.; Potier, P. Application of a modification of the Polonovski reaction to the synthesis of vinblastine-type alkaloids. J. Am. Chem. Soc. 1976, 98, 7017-7024. [CrossRef]

73. Kutney, J.P.; Hibino, T.; Jahngen, E.; Okutani, T.; Ratcliffe, A.H.; Treasurywala, A.M.; Wunderly, S. Total synthesis of indole and dihydroindole alkaloids. IX. Studies on the synthesis of bisindole alkaloids in the vinblastine-vincristine series. The biogenetic approach. Helv. Chim. Acta 1976, 59, 2858-2882. [CrossRef]

74. Gotoh, H.; Sears, J.E.; Eschenmoser, A.; Boger, D.L. New Insights into the Mechanism and an Expanded Scope of the Fe(III)-Mediated Vinblastine Coupling Reaction. J. Am. Chem. Soc. 2012, 134, 13240-13243. [CrossRef]

75. Boon, B.A.; Boger, D.L. Triarylaminium Radical Cation Promoted Coupling of Catharanthine with Vindoline: Diastereospecific Synthesis of Anhydrovinblastine and Reaction Scope. J. Am. Chem. Soc. 2019, 141, 14349-14355. [CrossRef]

76. Sottomayor, M.; Lopez-Serrano, M.; DiCosmo, F.; Barcelo, A.R. Purification and characterization of alpha-3', $4^{\prime}$-anhydrovinblastine synthase (peroxidase-like) from Catharanthus roseus (L) G. Don. FEBS Lett. 1998, 428, 299-303. [CrossRef]

77. Hamada, H.; Nakazawa, K. Biotransformation of vinblastine to vincristine by cell-suspension cultures of catharanthus-roseus. Biotechnol. Lett. 1991, 13, 805-806. [CrossRef]

78. Kumar, A.; Ahmad, A. Biotransformation of vinblastine to vincristine by the endophytic fungus Fusarium oxysporum isolated from Catharanthus roseus. Biocatal. Biotransform. 2013, 31, 89-93. [CrossRef]

79. Caputi, L.; Franke, J.; Farrow, S.C.; Chung, K.; Payne, R.M.E.; Trinh-Don, N.; Dang, T.-T.T.; Carqueijeiro, I.S.T.; Koudounas, K.; de Bernonville, T.D.; et al. Missing enzymes in the biosynthesis of the anticancer drug vinblastine in Madagascar periwinkle. Science 2018, 360, 1235-1238. [CrossRef] [PubMed]

80. Bonrath, W.; Netscher, T. Catalytic processes in vitamins synthesis and production. Appl. Catal. A-Gen. 2005, 280, 55-73. [CrossRef]

81. Netscher, T.; Bonrath, W.; Bendik, I.; Zimmermann, J.P.; Weber, F.; Rüttimann, A. Vitamins, 5. Vitamin K. In Ullmann's Encyclopedia of Industrial Chemistry; Wiley-VCH: Weinheim, Germany, 2005; pp. 1-25. [CrossRef]

82. Gross, J.; Cho, W.K.; Lezhneva, L.; Falk, J.; Krupinska, K.; Shinozaki, K.; Seki, M.; Herrmann, R.G.; Meurer, J. A plant locus essential for phylloquinone (vitamin K-1) biosynthesis originated from a fusion of four eubacterial genes. J. Biol. Chem. 2006, 281, 17189-17196. [CrossRef]

83. Tarento, T.D.C.; McClure, D.D.; Talbot, A.M.; Regtop,H.L.; Biffin, J.R.; Valtchev, P.; Dehghani, F.; Kavanagh, J.M. A potential biotechnological process for the sustainable production of vitamin K-1. Crit. Rev. Biotechnol. 2019, 39, 1-19. [CrossRef]

84. Liu, J.-M.; Solem, C.; Jensen, P.R. Harnessing biocompatible chemistry for developing improved and novel microbial cell factories. Microb. Biotechnol. 2019, 13, 54-66. [CrossRef]

85. Tarento, T.D.C.; McClure, D.D.; Dehghani, F.; Kavanagh, J.M. Pilot-scale production of phylloquinone (vitamin K-1) using a bubble column photo-bioreactor. Biochem. Eng. J. 2019, 150, 107243:1-107243:6. [CrossRef]

86. Hecht, K. Innovation in Biocatalysis-A Swiss Network Project Coordinated by the Competence Center for Biocatalysis (CCBIO). Chimia 2017, 71, 866-871. [CrossRef]

87. NCCR Master in Chemical Biology. Available online: https://nccr-chembio.ch/education-training/masters/ (accessed on 3 November 2020).

88. Major Biological Chemistry. Available online: https:/ethz.ch/content/dam/ethz/special-interest/biol/ department/BiologicalChemistry.pdf (accessed on 3 November 2020).

89. Biochemie-Chemische Biologie. Available online: https:/ethz.ch/content/dam/ethz/special-interest/chab/ chab-dept/studies/documents/C_CI/WL_BSc_BCB_okt2020.pdf (accessed on 3 November 2020).

90. INNOSUISSE. Available online: https://www.innosuisse.ch/inno/en/home.html (accessed on 9 November 2020).

91. BRIDGE. Available online: https://www.bridge.ch/en/ (accessed on 9 November 2020).

92. Hardy, M.A.; Wright, B.A.; Bachman, J.L.; Boit, T.B.; Haley, H.M.S.; Knapp, R.R.; Lusi, R.F.; Okada, T.; Tona, V.; Garg, N.K.; et al. Treating a Global Health Crisis with a Dose of Synthetic Chemistry. ACS Cent. Sci. 2020, 6, 1017-1030. [CrossRef] [PubMed]

93. Adams, J.P.; Brown, M.J.B.; Diaz-Rodriguez, A.; Lloyd, R.C.; Roiban, G.D. Biocatalysis: A Pharma Perspective. Adv. Synth. Catal. 2019, 361, 2421-2432. [CrossRef] 
94. Wohlgemuth, R. Building Bridges between Biotechnology and Chemistry-Oreste Ghisalba's Pioneering Activities, Publications and Programs. Chimia 2020, 74, 322-337. [CrossRef] [PubMed]

95. Wohlgemuth, R. Biocatalysis-Key enabling tools from biocatalytic one-step and multi-step reactions to biocatalytic total synthesis. N. Biotechnol. 2020, 60, 113-123. [CrossRef]

Publisher's Note: MDPI stays neutral with regard to jurisdictional claims in published maps and institutional affiliations.

(C) 2020 by the authors. Licensee MDPI, Basel, Switzerland. This article is an open access article distributed under the terms and conditions of the Creative Commons Attribution (CC BY) license (http://creativecommons.org/licenses/by/4.0/). 